\title{
La nueva Ley de Enjuiciamiento Civil española y la oralidad*
}

Juan Montero Aroca

\section{Introducción}

\section{En tierra mítica}

Está llegando el momento adecuado para que algún historiador del Derecho afronte el desafío de escribir la historia de la oralidad y de la escritura en el proceso civil. Esa historia, que deberá escribirse tanto desde la constatación de la existencia de mitos jurídicos como desde la superación de los mismos y de la adecuación a la experiencia, será muy difícil de redactar. Debo reconocer que en más de una ocasión he tenido que resistir a la tentación de hacer ese estudio y que mi resistencia se ha basado en el convencimiento de que me falta la necesaria imparcialidad. He sido durante demasiado tiempo uno de los afectados por el mito de la oralidad en el proceso civil y soy uno de los que están superándolo y empezando a intentar comprender la realidad.

En 1975, en ocasión académicamente comprometida, hube de redactar lo que entonces se llamaba "Memoria sobre el concepto del Derecho procesal», y entonces asumí, en su mayor parte, el mito de la oralidad que estaba difundido en la doctrina ${ }^{1}$. El paso del tiempo me

* Texto base de la conferencia pronunciada en las "XVII Jornadas Iberoamericanas de Derecho Procesal», celebradas en San José, Costa Rica, los días 18 a 20 de octubre de 2000 .

1 Un año después se convirtió en el libro titulado Introducción al Derecho Procesal. Jurisdicción, acción y proceso. Madrid, 1976; 2a edición, 1979. 
ha hecho recapacitar y me he dado cuenta de que aquellas veinte páginas respondieron a un momento de juvenil falta de criterio propio y de asunción de la fe recibida de los mayores sin atisbos críticos. Todos estos años después me están imponiendo, no una conversión a fe distinta, pero sí entrar en una fase de crisis de la vieja fe. El momento actual requiere ejercitar «la funesta manía de pensar» y, obviamente, de pensar por cuenta propia, hasta lograr que la vieja fe deje de ser una mera creencia para ser conocimiento científico.

No voy a escribir, pues, ni ahora ni después, la historia de los principios de escritura y de oralidad en el proceso civil, pero sí pretendo recapacitar sobre lo que han sido y lo que deben ser, y hacerlo aprovechando la ocasión de la nueva Ley procesal civil española, promulgada como Ley $N^{\circ} 1 / 2000$, de 7 de enero, de Enjuiciamiento Civil, con la que se ha producido en España, y precisamente en el último año del siglo XX, el acontecimiento jurídico más importante de este siglo. Un cuerpo jurídico como es un código procesal civil sólo es equiparable en su trascendencia social a un código civil, pero es mucho más trascendente que otros cuerpos legales, como el código penal o las leyes hipotecarias.

Los organizadores de estas «XVII Jornadas Iberoamericanas de Derecho Procesal" han demostrado sensibilidad a la hora de darse cuenta de que un código, que eso es realmente la llamada tradicionalmente Ley de Enjuiciamiento Civil en España, es un hito en el desarrollo de las normas reguladoras de la justicia civil. Después de siglos de un modelo de proceso, que ha arraigado muy profundamente en el solar hispano americano, se ha regulado un nuevo modelo. No se trata de una simple actualización o adecuación de la vieja ley a las nuevas necesidades; se trata de un cambio de modelo. La ruptura con lo anterior puede ser ocasión adecuada para que reflexionemos sobre cómo ha sido el viejo modelo procesal civil del derecho hispánico, basado en la escritura, que fue el mismo que en el de la mayoría de los países iberoamericanos ${ }^{2}$, y sobre cómo es el nuevo, basado en la oralidad sin excesos que desvirtúen lo que la oralidad realmente debe significar.

2 Pueden verse Juan Alberto Montero, Análisis crítico de la Ley de Enjuiciamiento Civil en su centenario, Madrid, 1982; "La Ley de Enjuiciamiento Civil española de 1855. La consolidación del proceso común", en L'Educazione Giuridica. VI/2. Modelli storici della procedura continentale, Perugia, 1994, pp. 347-458, y en 


\section{Sección Primera}

El viejo modelo procesal escrito (o el proceso de la LEC de 1881)

\section{Las partidas y el proceso ordinario}

Las Partidas son, sin duda, el monumento jurídico más importante de nuestra historia (la de todos los países de lengua española), no superadas hasta ahora ni siquiera por la codificación, pues gravitaron durante seis siglos sobre la vida española y durante cuatro sobre la de Iberoamérica $^{3}$, llegando vivas hasta el siglo XIX.

\section{Características esenciales}

Sin atender aquí a la discutida atribución de las Partidas al reinado de Alfonso X (1252-1284), ni a su finalidad política, ni a su estilo claramente doctrinal y justificador de lo que se ordena, sí hay que destacar:

a) Dada la situación del siglo XIII la obra sólo podía estar basada en la recepción del ius commune. Esto es algo que la doctrina española, desde la más antigua ${ }^{4}$, no ha discutido ${ }^{5}$, pues en las Partidas se encuentran ejemplos sobrados incluso de traducción de textos romanos.

El descubrimiento de la obra de Justiniano, a finales del siglo XI y principios del XII, supuso un nuevo método de estudiar el Derecho, sobre todo en la Escuela de Bolonia, en el que importa su consideración, primero, de que ese Derecho no era algo del pasado sino algo positivo y vigente todavía en el Imperio, lo que lo legitimaba políicamente, y, después, de que el mismo se correspondía con la razón natural, con la ratio iuris, lo que explica su gran prestigio y su inmediata difusión.

Ensayos de Derecho Procesal; Barcelona, 1996, pp. 169-275; La herencia procesal española, México, UNAM, 1994; Derecho Jurisdiccional, II. Proceso civil (con G.

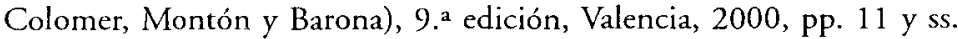

3 Couture, "Trayectoria y destino del derecho procesal civil en Hispanoamérica",

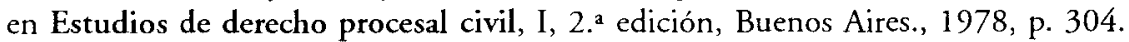

4 Diego de Covarrubias, "Opera omnia", II, Ginebra, 1723, folio 88, en Variarum resolutionum, I, XIV, 1.

5 Debe verse Pérez Martin, "El derecho procesal del "ius commune" en España, Murcia 1999. 
b) Atendido su contenido tuvieron una inmediata difusión y gran éxito entre la nueva clase de juristas profesionales que se estaba formando en el espíritu del Derecho común, si bien, correlativamente, provocó el rechazo del hombre común, que pretendía seguir rigiéndose por sus fueros y costumbres.

Antes de las Partidas no puede citarse en España nombre alguno de jurista procesalista, $y$ cuando aparecen esos nombres se trata de colaboradores de Alfonso $\mathrm{X}$ en su redacción, que o son italianos de origen $\mathrm{o}$ han estudiado en ese país. El nombre más importante es el de Jacobo de las Leyes, que fue el autor de la Partida III, la procesal. Estos juristas aparecen como un grupo o casta que cultiva una nueva ciencia, de la que queda excluido el pueblo llano, incluso por la lengua utilizada.

Asumido en las Partidas el Derecho común se produjo, por un lado, el rechazo de las mismas por el pueblo, lo que impidió incluso que llegaran a promulgarse como ley vigente, y, por otro, el que se difundiera entre los juristas, dándose el contrasentido de que una norma no promulgada fuera aplicada por los tribunales.

Hay que recordar que las Partidas fueron la última fuente, aplicable sólo de modo supletorio, desde el Ordenamiento de Alcalá (1348) y pasando por las Leyes de Toro (1505), pero que ello no impidió que de hecho su influencia llevara a que se aplicara como fuente primera. En la legislación posterior se parte implícitamente de que la norma aplicable es la contenida en las Partidas, y se trata de ir llenado lagunas de la misma o de modificarla en aspectos concretos.

\section{El proceso}

En la concepción del Derecho común las partes son «las dueñas de los pleitos» (los "señores de los pleytos") y por eso la Partida III se inicia con el estudio de las partes (demandador y demandado), siguiendo con el juez, para referirse después a los personeros o procuradores y a los boceros o abogados. Su principio básico es el de que el proceso es un drama entre tres personas, que sólo se inicia por una de las partes, de modo que ninguna persona puede ser obligada a demandar.

A partir de ahí el solemnis ordo iudiciarius respondía a la concepción de que las partes tenían que disponer con toda amplitud de los medios de ataque y de defensa que consideraran oportunos, planteando sin limitaciones el litigio que las separaba, porque se trataba de acabar para 
siempre con dicho litigio, de modo que la sentencia que se dictara tenía que producir los efectos de cosa juzgada material, no siendo posible otro proceso posterior. Lo anterior iba unido a la creencia de que ese proceso necesitaba un procedimiento complicado, lento y formalista y, por tanto, originador de un elevado coste, pues se trataba de ofrecer a las partes las mayores posibilidades para su defensa.

Junto con lo anterior caracterizará también a ese proceso el que se realiza de modo casi exclusivamente escrito, lo cual responde a necesidades sociales de muy variada concepción. Se trataba, por un lado, de controlar la actuación del juez, tanto en lo que se refiere a la realización de los actos procesales como en el contenido de las resoluciones judiciales, pero se trataba, también, de la idea de que la escritura suponía seguridad jurídica. La consecuencia fue la consagración de un brocardo que implica toda una manera de ver el proceso: quod non est in actis non est in mundo.

En el sistema del Derecho común el proceso ordinario es el proceso único, en el sentido de que no existen procesos especiales. Un proceso es ordinario cuando por medio del mismo pueden conocerse todo tipo de objetos o pretensiones, y un proceso es especial cuando está previsto para que por medio de él los órganos jurisdiccionales conozcan sólo de un objeto o pretensión determinada (retracto, desahucio, por ejemplo), y lo que estamos diciendo es que el proceso ordinario de las Partidas estaba previsto para todos los objetos, pues en todos ellos se trataba de ofrecer la misma defensa plena a las partes.

Esta concepción es la que se asume en las Partidas y la que se va a mantener en la base del proceso civil hasta la codificación, ya en el siglo XIX. Naturalmente en esos seis siglos se dictaron miles de normas dadas, bien en Cortes, bien por el rey, que fueron completando o modificando la regulación de aquéllas. Lo más grave es que esas normas no contenían disposición derogatoria, lo que produjo un fenómeno de acumulación normativa, en la que lo más difícil era llegar a saber qué es lo que estaba en vigor.

Las recopilaciones posteriores (Ordenamiento de Díaz de Montalvo, de 1484, el Libro de Bulas y Pragmáticas de Ramírez, de 1505, y la Nueva Recopilación, de 1567), fueron significando modificaciones parciales, pero la concepción del proceso ordinario no se alteró. Se siguió creyendo que un proceso, para decidir de modo definitivo una cuestión entre partes, necesitaba de muchas complicaciones, que eran 
imprescindibles si se quería ofrecer a aquéllas todas las posibilidades que precisaba su derecho de defensa.

\section{Los procesos plenarios rápidos}

La ineficacia de un proceso como el ordinario civil para solucionar con eficacia los conflictos entre partes, llevó a configurar un nuevo tipo procesal que, sin dejar de ser ordinario (de referirse a cualquier objeto) y plenario (en el que se producía cosa juzgada), significara reducir el tiempo y el dinero. Este nuevo tipo de proceso fue el plenario rápido.

El nuevo proceso tiene sus manifestaciones tanto en el Derecho canónico, principalmente en las Decretales de Clemente V Saepe contingit (de 1306) y Dispendiosam (de 1311), como en el Derecho civil, en el que las reformas provienen de los estatutos de las ciudades mercantiles italianas, $\mathrm{y}$ en los dos casos se trataba de la supresión de formalidades superfluas y concesión de facultades procesales (no materiales) al juez para repelerlas, de la suavización del principio de preclusión en aras de la elasticidad, de la limitación o supresión de apelaciones independientes contra las resoluciones interlocutorias, de acortamiento de los plazos, y, sobre todo, de predominio de la oralidad frente a la escritura.

\section{En el ámbito mercantil}

La recepción en España de la idea del proceso plenario rápido se produce, como es lógico, de modo mucho más acusado en el ámbito del Derecho mercantil, dándose lugar a la creación de un proceso para y entre mercaderes. Las manifestaciones primeras deben registrarse en la corona de Aragón, pero las que van a tener trascendencia posterior son las del reino de Castilla.

En la corona de Aragón el origen se encuentra en las ordenanzas dadas por Pedro III a Valencia, después de que en 1283 creara el Consulado del Mar de esta ciudad, que fueron adoptadas después por Palma de Mallorca, para regir el nuevo Consulado creado en 1343 por Pedro IV, y que se comunicaron en 1347 a Barcelona, cuando el mismo Pedro IV constituyó el tribunal consular. En el reino de Castilla el origen debe buscarse en la creación de los consulados, empezando por el de Burgos, en 1494, cuando los Reyes Católicos conceden jurisdic- 
ción al prior y cónsules de la universidad de mercaderes para que conozcan de los pleitos entre ellos, y a partir de ahí se inicia una muy compleja evolución con la creación de consulados en distintas ciudades. Con el paso del tiempo las ordenanzas de mayor prestigio fueron las de Bilbao de 1737.

Realmente estamos aquí ante la creación de tribunales especiales mercantiles, en los que la potestad jurisdiccional se atribuye al prior $y$ a los cónsules del Consulado, además de la regulación de un nuevo proceso. Este supuso una ruptura de concepción procedimental con el ordinario y básicamente respondía a estas características:

1) Conciliación previa obligatoria: si al principio el intento de conciliación fue voluntario, pronto se dispuso de modo obligatorio que el prior y cónsules debían intentar la conciliación entre las partes.

2) Prohibición de la intervención de abogados: desde las Ordenanzas de Burgos la misma existencia del Consulado se justificó con un ataque a los abogados, hasta el extremo de que en aquéllas se decía que los pleitos entre mercaderes «nunca se concluían ni fenecían, porque se presentaban escritos de libelos de letrados, por manera de que por mal pleyto que fuese, los sostenían los letrados, de manera que los hacían inmortales".

3) Oralidad: frente al proceso ordinario civil totalmente escrito, el mercantil pretendió encontrar la rapidez en la oralidad.

La fórmula tradicional fue: "simpliciter et de plano, ac sine strepitu et figura iudicii procedi mandamus" (de la Saepe contingit); "simpliciter et de plano, absque juditiorum strepitu et figura, sine libello litis contestatione et aliis solemnitatis et ordinibus iudiciorum etiam substancialibus" (Estatuto de Forli de 1369); “lo libren y determinen breve y sumariamente según estilo de mercaderes, sin dar luengas ni dilaciones ni plazos de abogados» (Ordenanzas de Burgos de 1494).

4) Aumento de los poderes procesales del juzgador: la oralidad y una cierta indeterminación procedimental, supuso la posibilidad de que el prior y los cónsules no se sintieran constreñidos por una legalidad estricta en la forma, pero ello desde luego no afectó a sus poderes materiales; éstos siguieron en manos de las partes.

También aquí hay fórmula que se repite en las distintas normas: «la verdad sabida y la buena fe guardada", o "atendida la sola verdad del hecho, según se ha acostumbrado a hacer a uso y estilo de mar». 


\section{En el civil}

Si el proceso mercantil rompe con el civil e inicia una vía propia, en la que el proceso plenario rápido aparece como alternativa al proceso ordinario, en el campo del proceso civil se manifestaron también algunos deseos de reforma. Estas se plasmaron en una doble dirección:

a) Por un lado, se trató de simplificar el proceso ordinario, de este modo se dispusieron medidas concretas relativas, por ejemplo, a permitir que se dicte sentencia aunque faltase alguna formalidad de las que "deben de ser puestas según la sutileza del Derecho" (en 1348), a la limitación de número escritos de las partes, fijando incluso el máximo de sus hojas (desde 1387 y con reiteración, lo que demuestra su incumplimiento), a la prohibición de las sentencia ilíquidas (en 1558), a la necesidad de declarar la rebeldía sólo una vez, no tres (en 1564), etc., aunque hay que dudar de la efectividad de todas estas medidas de aceleración del proceso.

b) Por otro lado, se procedió a la creación de un proceso plenario rápido, pues, aunque con algún antecedente en las Partidas, en 1534 se permitió un juicio rápido para asuntos civiles de pequeña cuantía, que fue manteniéndose en disposiciones posteriores, con sucesivas elevaciones de la cuantía. Su parentesco con el proceso mercantil es evidente y se encuentra aquí el origen del juicio verbal que se plasmó en las leyes de enjuiciamiento civil.

Como puede comprobarse la extensión de la idea del proceso plenario rápido al campo civil fue muy limitada, y no supuso una verdadera alteración de éste. Con todo, lo que importa destacar ahora es la existencia de dos sistemas procesales vigente durante muchos siglos, sistemas que permanecieron incomunicados entre sí, y especialmente que los juristas centraron su atención en el civil, sin atender al mercantil.

Los juristas hispano americanos que publican desde las Partidas hasta la Novísima Recopilación están inmersos en la creencia de que el proceso ordinario es el juicio tipo por excelencia, y que sobre él deben centrar sus esfuerzos de estudio y divulgación. Los juicios plenarios rápidos, y en especial el mercantil, no son merecedores de su atención, con la excepción de Hevia de Bolaños, que en 1603 y desde Lima da un ejemplo de modernidad ${ }^{6}$. 
En cualquier caso debe advertirse que en los procesos plenarios rápidos, sean mercantiles o civiles, no se produjo modificación alguna respecto de las facultades materiales del juez. Estos procesos son distintos del ordinario en el procedimiento, y con ello se está diciendo que asumen, por un lado, el principio de oralidad y que, por otro, aumentan los poderes procesales del juez, lo que manifestaba principalmente en la atribución de facultades para la dirección formal del proceso (y así la posibilidad de rechazar de oficio maniobras dilatorias de las partes).

\section{La codificación de los procesos civil y mercantil}

El siglo XIX conoce en su inicio la independencia de los países americanos, si bien la ruptura de la unidad procesal es algo que se va a ir produciendo a lo largo del siglo. Lo normal es que, en el inicio de la independencia política, se disponga de entrada que las leyes españolas quedan subsistentes mientras se van dictando las normas propias de cada república. A lo largo del siglo se va a ir produciendo la codificación y aquí atenderemos a la española, pues se trata de mostrar cómo se ha llegado a la Ley $\mathrm{N}^{\circ} 1 / 2000$.

Los dos sistemas procesales, el civil y el mercantil, llegan al siglo XIX sin relación entre sí y en los dos se advierte pronto la aspiración de codificar. La codificación no va a suponer la unificación de los dos sistemas, sino la consolidación de los mismos, hasta que desaparece el mercantil.

\section{La codificación del proceso mercantil}

El sistema procesal mercantil, o del proceso plenario rápido, llegó al siglo XIX con problemas derivados de dos causas. La primera se refería a la multiplicación de consulados con regulaciones diferentes, lo que provocaba confusión y largas cuestiones de competencia entre ellos. La segunda atendía a la indeterminación procedimental, origen de prácticas diferentes y de arbitrariedad por los priores y cónsules. Se estaba así ante la necesidad de unificar y regular.

A ello atendió el Código de Comercio de 1829 y la Ley de Enjuiciamiento sobre los negocios y causas de Comercio de 1830. El Código regulaba la "Administración de justicia en los negocios de comercio", 
basado en los tribunales de comercio, constituidos por el prior y dos cónsules, conociendo de la segunda y tercera instancia las Audiencias y luego, del recurso de injusticia notoria, el Consejo de Castilla (luego el Tribunal Supremo). La Ley regulaba dos clases de juicios:

1) El de mayor cuantía perdió alguno de los elementos que lo caracterizaban como plenario rápido, sobre todo el de la simplicidad, aproximándose al proceso ordinario civil. Basta advertir que constaba de primera instancia, segunda, tercera y recurso de injusticia notoria, aparte de que la oralidad sufrió un gran retroceso.

2) El de menor cuantía era el clásico juicio verbal, con demanda escrita preparatoria y citación de las partes a juicio, realizándose éste en audiencia única, no admitiéndose apelación contra la sentencia.

Esta Ley de Enjuiciamiento se mantuvo en vigor hasta 1868, por lo que a lo largo de la mayor parte del siglo XIX tuvimos en España tribunales especiales mercantiles y proceso propio. El Decreto de Unificación de Fueros supuso la desaparición de los tribunales y del proceso mercantiles, sin que las normas que había regulado el segundo tuvieran influencia alguna en la regulación del proceso civil, el ordinario.

\section{Hacia la codificación del proceso civil}

La regulación del proceso civil en el inicio del siglo XIX se encontraba en la Partida III y en el Libro XI de la Novísima Recopilación de 1805. El inicio de las reformas se encuentra en la Constitución de 1812 y, especialmente, en algunos decretos que dieron las Cortes de Cádiz, produciéndose después sucesivamente hasta la Ley de Enjuiciamiento Civil de 1855. Los pasos más importantes fueron:

a) En el Decreto de 9 de octubre de 1812, Reglamento de las Audiencias y Juzgados de Primera Instancia, se contenían tres clases juicios: 1) El juicio verbal, el que hemos dicho que procede de 1534 , con procedimiento muy poco determinado, 2) El juicio ordinario, que quedó íntegro y sin modificación alguna; y, 3) Un nuevo juicio, intermedio entre los dos anteriores por la cuantía, aunque sujeto a los principios propios del ordinario, incluida la escritura, al que no se le da denominación. 
b) El segundo paso fue el Decreto de 26 de setiembre de 1835, Reglamento provisional para la administración de justicia en lo respectivo a la Real jurisdicción ordinaria, que mantiene las tres clases de juicios, el último también sin denominación.

c) El paso decisivo fue obra de la Ley de 10 de enero de 1838, provisional para la substanciación de los juicios de menor cuantía, en la que el juicio intermedio tiene ya denominación pero, sobre todo, en la que se regula un verdadero proceso plenario rápido, sujeto a los principios de oralidad, concentración, inmediación, publicidad e impulso de oficio, y en el que todos los plazos eran perentorios e improrrogables.

d) El último paso a considerar es la Instrucción del marqués de Gerona, de 30 de septiembre de 1853, referida al proceso ordinario, en la que se trataba de hacer frente a los abusos, corruptelas, dilaciones innecesarias, prácticas ilegales que habían convertido al proceso ordinario en "la muerte de la justicia misma». En la Instrucción se introducía el impulso de oficio, concentración, publicidad, aumento de los poderes procesales del juez, supresión de trámites.

La Ley de 1838 y el sistema de principios que informaban al juicio de menor cuantía, chocaba frontalmente con el resto de la legislación procesal y, precisamente por eso, fue rechazada por la doctrina y la práctica, apegadas una y otra a las viejas concepciones. La Instrucción no pudo mantenerse en vigor ocho meses.

La opinión de la doctrina y la práctica de la época respecto del proceso ordinario puede sintetizarse así:

1) Se creía en la bondad de la legislación tradicional, hasta el extremo de considerar que era la envidia de Europa.

2) La excelente legislación vigente había sido oscurecida por corruptelas que era preciso suprimir, pero manteniendo el sistema.

3) El proceso lento y complicado era la salvaguardia de los derechos de las partes y las solemnidades en el juicio garantía de la seguridad jurídica. Dentro de esas solemnidades la escritura era elemento base de la seguridad.

4) Las partes debían seguir siendo las "dueñas del proceso», sin conceder facultades de dirección del proceso al juez, para asegurar la imparcialidad de éste. Las facultades materiales ni se cuestionan y el aumento de las procesales se rechazan expresamente. 
5) La lentitud de la justicia se debía al gran volumen de asuntos, por lo que debía aumentarse el número de tribunales.

La doctrina y la práctica estaban conformes con el sistema procesal. Era necesario aclarar y simplificar, pero no innovar. Acabar con las corruptelas, pero mantener los principios, aumentando el número de órganos jurisdiccionales.

\section{La ley de enjuiciamiento civil de 1855}

Los que se opusieron a la Ley de 1838 y los que consiguieron la derogación de la Instrucción de 1853, fueron los que se encargaron de la redacción de la primera ley procesal civil, la Ley de Enjuiciamiento Civil de 5 de octubre de 1855. Para entender como ésta produjo la petrificación del viejo sistema del proceso ordinario, basta atender a las bases de la misma.

En el mismo año de 1855 las Cortes aprobaron una Ley de Bases denominada "para la reforma de los procedimientos en los juicios civiles", por medio de la que se pretendía uordenar y compilar las leyes y reglas del enjuiciamiento civil», con el fin de "restablecer en toda su pureza las reglas cardinales de los juicios consignadas en nuestras antiguas leyes». No se trataba, pues, de innovar, sino de consolidar lo existente.

En la Exposición de Motivos de la Ley de Bases queda claro que la revisión que se debía hacer no pretendía "la destrucción de los fundamentos venerables sobre los que descansa la obra secular de nuestras instituciones procesales. Su objeto, por el contrario, debe ser dar nueva fuerza a los principios cardinales de las antiguas leyes, principios basados en la ciencia, incrustados por más de veinte generaciones en nuestras costumbres, aprendidos como tradición hasta por las personas ignorantes del derecho, y con los cuales pueden desenvolverse con sobrada anchura todos los progresos, todas las reformas convenientes».

Desde estos planteamientos el sistema de principios de la ley respondió al viejo juicio ordinario, que se asumió íntegramente, de modo que la ley se articuló sobre ese juicio. La comprensión de este fenómeno jurídico es esencial para entender la evolución procesal civil de Iberoamérica. Esta Ley de 1855 ha sido, como demostró Alcalá- 
Zamora ${ }^{7}$, "el código procesal más prolífico del universo", y por poner un ejemplo de su influencia bastará recordar que Alsina demostró que, de los ochocientos diez artículos del Código argentino de 1880, trescientos noventidós tienen su fuente directa en aquella ley ${ }^{8}$. Se trata, por tanto, de una ley (un código) que determinó todo el desarrollo posterior de lo que ha sido el proceso civil de muchos países?

\section{A) Principios del proceso}

El proceso civil se concibe como un medio de solucionar contiendas privadas, en las que el juez cumple una función de pacífico mediador, siendo las partes las que asumían todas las facultades. Esto supuso la plasmación del principio dispositivo (lo que es obvio en la actuación del Derecho privado) y el de aportación de parte (entendido éste en su más amplio sentido, incluyendo todo lo relativo a la prueba, que era "cosa de las partes»), pero sobre todo que en lo que se refiere a las facultades procesales de dirección:

1) El juez no tenía control de oficio de los presupuestos procesales. El principio general era el de que "nada debe hacerse oficio en los negocios civiles, sino que debe dejarse todo al interés de la parte y a su excitación" (lo que supuso que no había verdaderos presupuestos procesales, siendo todos impedimentos).

7 Alcalá-Zamora por ejemplo en Nuevos estudios de Derecho procesal, Madrid, 1980, p. 300. Puede verse también Couture, "Trayectoria y destino del Derecho procesal civil hispano-americano", en Estudios de Derecho Procesal, I, $2^{\text {a }}$ edición, Buenos Aires, 1978, p. 307, y Fundamentos de derecho procesal civil, $3^{2}$ edición, reimpresión, Buenos Aires, 1966, pp. 166-167.

8 Alsina, "Influencia de la Ley española de enjuiciamiento civil de 1855 en la legislación procesal argentina», en Actas del I Congreso Ibero-Americano y Filipino de Derecho Procesal, Madrid, 1955, pp. 291-309, y en Revista de Derecho Procesal (Argentina), 1955, I, pp., 27-43.

9 Posiblemente la mejor demostración de lo que decimos se encuentra en el éxito del libro de José de Vicente y Caravantes, Tratado histórico, crítico y filosófico de los procedimientos judiciales en materia civil, según la nueva Ley de Enjuiciamiento, Madrid, 1856-58, 3 volúmenes; Apéndice, Madrid, 1867, y otro Apéndice, Madrid, 1879. Es dificil encontrar un libro de derecho procesal español que haya tenido tanta influencia en América, y recordamos perfectamente que en México y otros países se adaptaron obras como las de Hevia de Bolaños, Sala, Tapia, y otros. 
2) El impulso procesal se confió a las partes. El proceso tenía que avanzar a instancia de parte, pues éstas debian solicitar al juez que declarase terminada una fase procesal y abriese la siguiente. De este modo todos los plazos quedaban a la discrecionalidad de las partes, pues no se entendía precluido un trámite mientras una parte no lo pidiera al juez expresamente.

Naturalmente la ley no pudo mantener el sistema de valoración legal en todos los medios de prueba, pues ello iba contra la lógica de los tiempos, pero se inventó la «sana crítica» que, en aquel momento, no era una manera de decir que la valoración de la prueba debía motivarse en la sentencia, sino un modo de pretender limitar el arbitrio judicial.

\section{Principios del procedimiento}

La ley proclamó la escritura como principio básico y la mantuvo con todas sus consecuencias de mediación y dispersión de los actos procesales. El brocardo quod non est in actis non est in mundo reflejaba exactamente la concepción de que el juez, para dictar sentencia, sólo podía tomar como base aquello que se encontraba documentado. Pero son mucho más significativos otros dos aspectos.

a) Secreto: la ley mantenía parcelas importantes de secreto en las actuaciones puesto que, si bien las vistas de los pleitos serán públicas, en la práctica de la prueba no se admitía: 1) Ni la publicidad general, o para el público, 2) Ni la presencia de la parte contraria en las pruebas de confesión o testifical, con lo que se limitaba el principio de contradicción.

b) Juicio de menor cuantía: la concepción general de la ley llevó a desvirtuar este juicio tal y como lo reguló la Ley de 1838; sus principios inspiradores en ésta (oralidad, concentración, inmediación, impulso de oficio, plazos improrrogables) quedan abandonados, estimándose que debía aplicarse lo dispuesto para el juicio ordinario, haciendo algunas variaciones meramente procedimentales de simplificación de trámites y de reducción de plazos.

El principal autor de esta LEC de 1855, Pedro Gómez de la Serna, dejó claro que la comisión redactora «tuvo por punto de partida lo 
tradicional, lo español, lo consignado en nuestro foro", de modo que la ley se centra en el juicio ordinario, el cual al mismo tiempo era la fórmula general de los juicios que carecieran de tramitación especial y el tipo supletorio de los especiales. Sobre este juicio "poco tuvo la comisión que discutir [...] sólo era necesario purificarlo de las prácticas viciosas que habían afectado la mejor obra sin duda de nuestras instituciones procesales" ${ }^{10}$.

\section{La exclusión de influencias externas}

Como hemos ido viendo, la codificación procesal civil supuso la consolidación de lo dispuesto en nuestras viejas leyes, principalmente las Partidas, y su concepción del viejo solemnis ordo iudiciarius. Destaquemos ahora que lo contrario estaba sucediendo en los demás países de Europa.

Durante siglos el ordo iudiciarius se consideró manifestación de la racionalidad que se iba creando por la intervención de los jueces y abogados, de modo que las reglas del mismo no eran susceptibles de ser impuestas desde fuera, por la autoridad de un legislador estatal. El legislador podía incidir en la regulación del proceso ordinario por medio de reformas parciales, tendentes a evitar corruptelas o prácticas viciosas, pero no podía alterarla completamente.

Como ha explicado Picardi, el ordo iudiciarius no sólo garantizaba el derecho de defensa en los juicios, sino también la resistencia frente a las autoridades externas. El proceso se concebía como algo originario, que respondía a las reglas de un arte, de las que nadie podía prescindir. La intervención del rey, o de cualquier legislador externo, hubiera representado una perversio ordinis, una acción odiosa, inadmisible, tanto como la alteración de la moneda o la imposición de reglas al médico ${ }^{11}$.

La situación empieza a cambiar cuando en 1667 se dicta el llamado Code Louis, que realmente fue la Ordonnance civile touchant la reformation de la Justicie, en la que por primera vez de modo directo el

10 Pedro Gómez de la Serna, Motivos de las variaciones principales que ha introducido en los procedimientos la Ley de Enjuiciamiento Civil, Madrid, 1857, p. 65.

11 Code Louis Picardi. "T. I Ordonnance civile», 1667, en Testi e documenti per la storia del proceso. I, a cura de Picardi y Giuliani, Milano, 1996, Introduzione. 
rey Luis XIV afirmó el monopolio real sobre la legislación en materia procesal civil. Ese monopolio no supuso, de momento, la ruptura total frente a lo anterior, pero sí la introducción de reformas de mucho calado.

Pueden ponerse muchos ejemplos, pero bastará con algunos significativos: 1) Frente a la existencia de cuatro o cinco escritos de alegaciones por cada parte en el inicio del proceso, se suprimieron la mayor parte de ellos, dejándolos reducidos a dos, 2) La vieja práctica de la litis contestatio que se manifestaba en la existencia de un acto formal, que a veces era incluso una sentencia llamada interlocutoria, se suprimió, 3) Todo lo relativo a las preclusiones, a las que era contrario el viejo sistema, recibió nueva regulación, admitiéndose la necesidad de la preclusión misma, como único medio para que el proceso pudiera avanzar, aunque no se llegó a un sistema rígido, y 4) La importancia tradicional de la prueba testifical cedió a favor de la prueba documental, limitando el valor de aquélla e incluso prohibiéndola en algunos supuestos (los relativos a negocios jurídicos de cuantía económica importante).

A pesar de todo lo anterior lo más significativo fue la admisión de procesos plenarios rápidos frente al proceso ordinario, con lo que éste dejaba de ser el único e, incluso, el esencial. Además, el juez quedaba sometido de modo claro a la ley, precisamente a aquélla que dictaba el rey.

La Ordenanza puso en marcha una nueva manera de entender el proceso, que va a concluir con el Code de procédure civile de 1806 de Napoleón, el cual servirá de base a la mayor parte de los códigos que se promulgan en Europa en el siglo XIX. El caso más claro es el de los códigos italianos, incluido el nacional de 1865 . Esto no ocurre en España, en la que la LEC de 1855 mantuvo la tradición del viejo proceso ordinario basado en el Derecho común.

\section{La ley de enjuiciamiento de 1881}

En la evolución española que estamos describiendo hito fundamental fue el Decreto de Unificación de Fueros de 1868, con el que se suprimieron los tribunales de comercio y el proceso mercantil, convirtiéndose los tribunales ordinarios en los únicos competentes para conocer 
de la aplicación del derecho privado. La unificación de fueros supuso la unificación de los procesos civil y mercantil, no por fusión, sino por supresión, quedando sólo en pie el peor de ellos. El proceso mercantil, que tantos siglos de experiencia acumulaba, simplemente desapareció.

La derogación de la Ley de 1830 se quiso paliar ordenando la realización de una nueva Ley de Enjuiciamiento Civil. A ese efecto se promulgó la Ley de Bases de 21 de junio de 1980, en la que se advierten simplemente reformas de detalle con relación a la LEC de 1855. Esta Ley se convierte en la base más importante, pues se trataba simplemente de «introducir en la ley actual [...] las reformas y modificaciones que la ciencia y la experiencia aconsejen como convenientes» (base 19.a). Se vuelve así a insistir en que «el juicio ordinario, reducido por la Ley de 1855 a sus proporciones esenciales, apenas reclamaba nuevas y fundamentales reformas", por lo que si no fuese por otras materias "realmente no sería necesaria la reforma de la ley vigente de enjuiciamiento» ${ }^{12}$.

A finales del siglo XIX se dictó, pues, la Ley de Enjuiciamiento Civil de 1881 en la que se trataba también de mantener lo existente, sin introducir verdaderas reformas en el sistema procesal civil. No es necesario, pues, repetir lo que antes hemos dicho para los principios del proceso y del procedimiento, pues los de la LEC de 1855 se reiteran en la de 1881, sin perjuicio de que en ésta se introdujo la publicidad general de los actos procesales y se aumentó la contradicción en la prueba.

Como dijo Goldschmidt el proceso civil español era «un recipiente liberal del siglo XIX, en el que se ha vaciado el vino antiguo del proceso civil de los siglos pasados» ${ }^{13}$, y como dijo Guasp «lo que el legislador de 1880 tomó del proceso común fue su técnica arcaica e insuficiente lógicamente dada la discordantia temporis, y afianzó esta técnica, con sus defectos fundamentales, en pensamientos políticos de innegable significación liberal»" ${ }^{14}$.

12 Diario de Sesiones, Senado, núm. 105, pp. 1547 y 1544.

13 James Goldschmidt, Derecho procesal civil, traducción de Prieto-Castro y Adiciones de Alcalá-Zamora, Barcelona, 1936, p. X.

14 Guasp, Comentarios a la Ley de Enjuiciamiento Civil, I, Madrid, 1943, p. 54. 


\section{Los fenómenos de huida}

Lo que sí importa destacar es que en el siglo largo de vigencia de la Ley de Enjuiciamiento Civil de 1881 se han producido dos fenómenos muy significativos de huida, que han puesto de manifiesto la falta de adecuación a la realidad, primero, del juicio ordinario de mayor cuantía, $y$, luego, de la propia ley.

\section{A) Huida del juicio de mayor cuantía}

Hemos asistido, en primer lugar, a una huida del juicio ordinario, que se llamaba de mayor cuantía, de modo que el mismo al final había quedado prácticamente excluido de la normal aplicación.

Los sucesivos legisladores parciales fueron conscientes de que el proceso ordinario medieval, el que se asumió en la LEC de 1881 como juicio de mayor cuantía, no podía seguir siendo aquél por el se tramitaban la mayor parte de los asuntos, dada su extraordinaria complejidad, y poco a poco, por medios de sucesivas elevaciones de la cuantía acabaron por convertirlo en un "cementerio de elefantes" por el que se conocían muy escasos asuntos.

Debe, en este sentido, tenerse en cuenta que si en 1881 el tope mínimo de la cuantía de un asunto que se tramitaba como juicio de mayor cuantía era de 1,500 pesetas, en 1984 se elevó a 100 millones y en 1992 quedó en 160 millones de pesetas (sobre un millón de dólares). Por este sistema dicho juicio fue desapareciendo de la realidad, pues son muy escasos los pleitos que superan esa cantidad. Acabó así siendo el juicio normal el de menor cuantía, que si en el origen comprendía los asuntos entre 250 y 1.500 pesetas, en 1992 pasaron a ser los de cuantía entre 800.000 pesetas y 160 millones de pesetas. Además, a esa tramitación se recondujeron los asuntos de cuantía indeterminada.

\section{B) Huida de la LEC}

La huida más importante, con todo, fue la propia LEC, lo que se hizo a base de regular un número extraordinariamente grande de procesos especiales, dando lugar a una verdadera proliferación procedimental.

Este fenómeno de proliferación se ha considerado normalmente como un defecto técnico procesal, centrándose su estudio en que el 
legislador, en casi todas las leyes materiales, se ha sentido en la necesidad de dotarlas de un proceso específico, y ello hasta el extremo de que podían contarse por lo menos cuarenta modos diferentes de tramitar los asuntos en primera instancia, es decir, cuarenta procesos especiales ${ }^{15}$.

Pero la proliferación fue algo más que una cuestión de técnica procesal. Supuso la configuración de tutelas judiciales privilegiadas frente a la tutela judicial ordinaria que se prestaba por medio de los procesos de la LEC. En efecto, la regulación de procesos especiales respondía, en la mayor parte de los casos, a la existencia de fuerzas sociales capaces de lograr del legislador la creación de tutelas propias frente a la tutela normal que se prestaba por los procesos ordinarios. Determinados titulares de derechos (sobre todo del de propiedad) y determinados grupos sociales (grandes acreedores), consiguieron del legislador que sus asuntos no se sometieran a la tutela normal, y que se les creara una tutela distinta, que por lo mismo sólo puede concebirse como privilegiada.

\section{Las reformas parciales}

Junto a todo lo anterior deben tenerse en cuenta algunas de las reformas importantes de la LEC de 1881. Su promulgación produjo una importante reacción contraria doctrinal y práctica, que propuso su inmediata reforma, pero el caso fue que la ley se mantuvo alrededor de cincuenta años sin que fuera objeto de modificaciones de importancia. En los años treinta del siglo XX se produjo una segunda oleada de críticas que tampoco consiguió frutos de interés.

15 El caso más claro de sinceridad legislativa fue el de la Exposición de motivos de la Ley de Sociedades Anónimas de 1951, en la que se reguló un proceso especial para la impugnación de los acuerdos de la junta general. Se decía allí que "si se quería evitar que la impugnación de los acuerdos de las Juntas generales, como medio de garantizar los derechos de las minorías, quedase reducida a una reforma platónica, como necesariamente tenía que ser, subsistiendo la necesidad de acudir a un juicio declarativo de mayor cuantía con sus instancias y un recurso de casación, para conseguir la anulación de los acuerdos de la Junta. A tal fin se articula un procedimiento especial de tramitación abreviada, que será aplicable mientras la reforma de nuestras leyes de procedimiento no hagan innecesario el que ahora se instaura para estos concretos fines". 
Con la moda de los tiempos, y no faltando manifestaciones reformistas, los años sesenta y setenta fueron de aspiración de dejar las cosas como estaban, de no romper con el pasado, de mantener la tradición jurídica española, de respeto a nuestro predecesores ${ }^{16}$, y tanto fue así que en la conmemoración del centenario de la LEC no faltó quien defendió su mantenimiento con pequeñas reformas, imputando los males de la realidad, no a la ley, sino a algunos aplicadores de la misma.

La situación, con todo, se hizo insostenible en la realidad, sobre todo como consecuencia del extraordinario aumento en el número de asuntos $^{17}$. La LEC pudo hacer frente, mejor o peor, a una situación en la que la sociedad era predominantemente rural y los conflictos eran los propios de la misma, pero se manifestó profundamente inadecuada para solucionar los conflictos propios de una sociedad urbana. Las nuevas necesidades exigían una nueva ley, pero los sucesivos legisladores prefirieron acudir a la técnica de las leyes de reforma urgente y parcial de la LEC. Esa técnica se utilizó principalmente en las siguientes leyes:

1) La Ley 34/1984, de 6 de agosto, de reforma urgente de la LEC, que en su Exposición de Motivos dijo responder «a las necesidades más apremiantes" mientras se procedía "con el cuidadoso tacto que requiere el tratamiento de la ordenación del proceso» al estudio del que "podría ser el nuevo ordenamiento procesal». En esta ley el juicio de menor cuantía se convirtió en el juicio tipo, desplazando al de mayor cuantía, aunque ello se hizo a base de desnaturalizar a aquél que dejó de ser un plenario rápido.

2) La Ley 10/1992, de 30 de abril, de medidas urgentes de reforma procesal, en cuya Exposición de motivos volvió a decirse que la reforma del ordenamiento procesal debía acometerse sin precipitaciones y ponderando cuantos elementos confluyen en el proceso, pero volviendo a dejar para sine die la verdadera reforma, conten-

16 El ejemplo más claro es el de Prieto-Castro, Temas de Derecho actual y su práctica, Salamanca, 1979, pp., 238 y 239, y la Exposición de motivos del Tomo I de Corrección y actualización de la Ley de Enjuiciamiento Civil, Madrid, 1972.

17 Hemos sostenido en Montero, El Derecho procesal en el siglo XX, Valencia, 2000, que el aumento de la litigiosidad en la segunda mitad del siglo ha condicionado toda la evolución. 
tándose con atender a aspectos de detalle $y$, sobre todo, a procurar «quitar papel» de los tribunales ${ }^{18}$.

El sistema de las reformas urgentes se reveló insuficiente para atender a las necesidades de la realidad y era preciso abordar una nueva LEC. Para ese fin el Ministerio de Justicia difundió en abril de 1997 un llamado "borrador", sometiéndolo a la consideración y sugerencias de todos los interesados. En diciembre de 1997 se dio a conocer el Anteproyecto, y el Consejo de Ministros de 30 de noviembre de 1998 remitió a las Cortes el oportuno proyecto de ley, que se ha convertido en la Ley $1 / 2000$, de 7 de enero, de Enjuiciamiento Civil.

\section{Sección Segunda}

La oralidad entre el mito y la realidad (o de la ideología autoritaria)

Decir que la diferencia entre las leyes de Enjuiciamiento Civil, la de 1881 y la de 2000 , consiste en que la primera regulaba un proceso escrito mientras que la segunda regula un proceso oral, siendo verdad, no es toda la verdad. La LEC de 2000 regula un proceso predominantemente oral, sí, pero lo hace atendiendo al sentido estricto del principio, no a los desbordamientos, muchos de ellos de contenido claramente político, que el principio ha sufrido a lo largo del siglo XX. Es por ello necesario atender a la evolución de la oralidad.

\section{El planteamiento inicial de Chiovenda}

La conversión de la oralidad en mito no creo que pueda decirse que proviene de la asunción de aquélla en el Código de Procedimiento Civil de Hanóver de 1850 o en la Ordenanza Procesal Civil alemana de 1877, y ello a pesar de que en estos cuerpos legales se produjo una asunción completa, tanto que ha podido calificarse de rígida y de dogmática ${ }^{19}$. Recuérdese simplemente que el parágrafo 128 de la segunda

18 Montero, "Las medidas urgentes de reforma procesal civil en la Ley 10/1992, de 30 de abril", en Ensayos de Derecho Procesal, Barcelona, 1996, pp. 277 y ss.

19 Debe verse Wach, "Oralidad y escritura», en Conferencias sobre la Ordenanza Procesal Civil alemana, traducción de Krotoschin, Buenos Aires, 1951. 
dice que «la discusión del asunto por las partes ante el tribunal que conozca del mismo será oral” y que, originariamente, sólo lo aportado de modo oral podía ser tomado en cuenta la decisión judicial. Mucho menos el mito puede tener su origen en la Ordenanza Procesal civil austríaca de 1895, obra de Klein, pues en ella la oralidad queda sujeta a límites mucho más razonables.

\section{La oralidad y la reforma radical}

El mito de la oralidad en el proceso civil, que ha corrido a lo largo del siglo XX, tiene su origen en Chiovenda y es necesario atender con algún detalle a su nacimiento para poder comprender todo el desarrollo posterior que lo ha conducido, en alguna de sus manifestaciones doctrinales, al absurdo.

En la edición de 1930-31 de los Saggi decía Chiovenda, en nota a pie de página del titulado Le riforme processuali e le correnti del pensiero moderno, que reproduce la conferencia pronunciada en Nápoles en 1906: "Con esta conferencia y con la publicación producida en el mismo año de la primera edición de mis Principii, se inició la propaganda por mí realizada en el último cuarto de siglo para la reforma del proceso civil italiano sobre la base de la oralidad, de la inmediación y de la concentración ${ }^{20}$. La propaganda y, como veremos después, el apostolado de Chiovenda elevaron la oralidad a mito jurídico y otros después contribuyeron a desnaturalizarlo. Contemos los hechos ${ }^{21}$.

\section{A) De la reforma de la conciencia de los hombres}

En marzo de 1906 pronuncia Chiovenda una conferencia en el Círculo Jurídico de Nápoles, con el título Las reformas procesales y las corrientes del pensamiento moderno, en la que después de una larga introducción sobre la importancia política y social del proceso civil, sobre la

20 Estamos utilizando la edición realizada por Proto Pisani de Chiovenda, Saggi di diritto processuale civile (1894-1937), Volume Primo, Milano, 1993, pp. 379-380.

21 Con la ayuda de Cipriani, Storie di processualisti e di oligarchi. La procedura civile nel regno d'Italia (1866-1936), Milano, 1991; Il Codice di procedura civile tra gerarchi e processualisti, Napoli, 1992, e Ideologie e modelli del proceso civile, Nápoles, 1997. 
influencia de las reformas políticas en las leyes procesales, con alusión a tratados internacionales, afirma la inadecuación del Código procesal italiano de 1865 a las condiciones de la sociedad y de la cultura de la época, para concluir que la solución «no será fruto de una reforma legislativa, ni de una reforma radical, sino sólo de una lenta y profunda modificación de nuestra conciencia y de nuestros sentimientos".

En este contexto de conservadurismo iluminado, de defensa de los abogados y de indeterminación de las reformas necesarias, hizo dos alusiones a la oralidad; una de pasada y otra algo más concreta, pero no para proponerla como modelo, sino sólo con referencia a Austria y a la Ordenanza de Klein. Dijo sólo que el proceso austríaco «ha spinto alle sue estreme applicazioni il principio della oralità; el mismo se basa en la concentración normal de todas las actividades procesales en una única audiencia, destinada a las alegaciones de fondo por las partes, a las pruebas, al debate ${ }^{22}$.

Estas dos únicas alusiones no pueden entenderse como el inicio de la propaganda sobre la oralidad. Este se encuentra en la conferencia pronunciada por Chiovenda en 1909, y en el Círculo Jurídico de Roma con el título El estado actual del proceso civil en Italia y el proyecto Orlando de reformas procesales, pues en este otro texto sí se ocupa ampliamente de la oralidad y sí afirma que en ella se encuentra la reforma radical que Italia necesita.

B) A la reforma radical del proceso civil

Antes de entrar a precisar lo que Chiovenda entendía entonces por oralidad es preciso atender a dos circunstancias:

a) El proyecto Orlando

El 16 de marzo de 1908 el ministro V. E. Orlando presentó en la Cámara de Diputados el proyecto de ley titulado «Nuevas disposiciones en torno al orden y a la forma de los juicios", proyecto que se debía a la pluma de Mortara y que no llegó a ser discutido por la disolución anticipada del Parlamento. En el Gobierno siguiente el mismo Orlando presentó un segundo proyecto, que también lleva 
su nombre, el 24 de mayo de 1909, también obra de Mortara, y titulado "Reformas al Código de procedimiento civil» que tampoco fue discutido ${ }^{23}$. La iniciativa legislativa terminó aquí, porque el siguiente ministro de Justicia fue Vittorio Scialoja, precisamente el maestro de Chiovenda ${ }^{24}$.

b) La reforma radical de Scialoja

Entre 1906 y 1909 se había producido un hecho aparentemente sin relación con el principio de oralidad, pero que va a condicionar todo el desarrollo del mismo y desde el inicio. El maestro de Chiovenda, quien lo había hecho catedrático de la Universidad de Roma a la tempranísima edad de 34 años y por chiara fama, sufrió una repentina conversión que le llevó a ser apóstol de la idea de que «no podemos continuar manteniendo un derecho general que es inferior al de todos los otros pueblos civilizados ${ }^{25}$.

En estas circunstancias, ante un proyecto de ley que contenía pequeñas reformas y con un maestro que se declaraba apóstol de la reforma radical, Chiovenda tuvo que abandonar su anterior posición de modificación de la conciencia y de los sentimientos para convertirse a la nueva fe de la reforma radical. Esa conversión consistió en llegar a ser el apóstol de la oralidad; su camino de Damasco fue indirecto, pues el converso primero fue Scialoja y Chiovenda lo fue sólo en segundo grado.

2. El contenido de la oralidad chiovendiana

Realmente Chiovenda en su conferencia de 1909 no estableció de modo general y teórico cuál era el contenido del principio de oralidad, sino

23 Los dos proyectos pueden verse en Tarzia y Cavallone, I progetti di riforma del processo civile (1866-1935), II, Milano, 1989, pp. 847 y ss. Están precedidos de una nota introductoria, redactada por Cavallone, que aporta muchos datos para conocer la época.

24 En la conferencia Chiovenda pudo tener en cuenta sólo el texto primero del proyecto, pues la conferencia misma se pronunció el 17 de abril y el segundo proyecto se presentó el 24 de mayo, siempre de 1909. Más aún, cuando se publicó la conferencia en 1910 no se introdujo añadido alguno.

25 Debe verse Cipriani, Storie di processualisti e di oligarchi, Op. cit., p. 143. 
que pretendió resumir los principios fundamentales de los procesos alemán y austríaco, lo que los diferenciaban del proceso italiano. Como la vida no se paró en 1909 estimamos preferible no atender a ese momento histórico, sino al último en que Chiovenda realizó un resumen de su concepción de la oralidad. Vamos a centrarnos en las Instituciones $^{26}$.

\section{A) Los principios integrados en la oralidad}

La palabra oralidad se adopta por la necesidad de expresar, de una forma simple y representativa, un complejo de ideas y características; en realidad un conjunto de principios, que son:

a) Predominio de la palabra hablada como medio de expresión, si bien atenuado por el uso de escritos de preparación y de documentación.

Partiendo de que es difícil imaginar un proceso oral que no admita actos escritos, sea de preparación, sea de documentación, lo que identifica realmente a la oralidad es que:

1) Los escritos preparatorios no son la forma de hacer las partes sus aportaciones al proceso, sino el anuncio de las declaraciones que van a hacer en la audiencia. Salvado el caso de la demanda, en la oralidad las declaraciones con eficacia jurídica sólo se hacen en la audiencia, y tanto es así que una declaración no se considera hecha si no se hace oralmente, bien directamente, bien por referencia.

2) Los escritos de documentación sirven para dar cuenta de lo ocurrido, principalmente en la audiencia; el acta de ésta documenta, bien las alegaciones de las partes no contenidas en los escritos iniciales, bien

$26 \mathrm{Al}$ final del tercer volumen de los Saggi en la edición de Proto Pisani, y a la que antes nos hemos referido, aparece la bibliografía de Chiovenda, realizada por Cipriani, y ahí puede verse que las Istituzioni di diritto processuale civile se publicaron el tomo I en 1933 y el II en 1934, con una segunda edición, respectivamente, en 1935 y en 1936. Sobre la segunda edición realizó su traducción Gómez Orbaneja, Instituciones de derecho procesal civil, publicada en tres volúmenes, el I en Madrid, 1936, y los otros dos en 1940. De la oralidad se ocupa el volumen III, pp. 159-165. 
las respuestas de las personas interrogadas como partes, testigos o peritos, bien las resoluciones distintas de la sentencia. Las actas no sirven de ayuda para la memoria del juez que debe fallar, sino de documentación de la actividad procesal para las instancias posteriores ${ }^{27}$.

b) Inmediación de la relación entre el juzgador y las personas cuyas declaraciones tiene aquél que valorar.

Este principio exige que el juez que debe pronunciar la sentencia haya asistido a la práctica de las pruebas de que saca su convencimiento, y haya entrado, por tanto, en relación directa con las partes, con los testigos, con los peritos y con los objetos del juicio, de forma que pueda apreciar las declaraciones de tales personas y las condiciones de los sitios fundándose en la impresión inmediata recibida de ellos y no en referencias ajenas. Este principio no sólo está unido al de la oralidad, pues sólo en un proceso oral cabe inmediación, es que constituye la esencia del proceso oral.

c) Identidad de las personas físicas que constituyen el tribunal durante la duración del juicio.

Principio derivado de los anteriores pero con sustantividad propia, significa que: $1^{\circ}$ En los tribunales colegiados la actividad procesal (sobre todo las pruebas) debe realizarse delante del colegio y no ante un juez delegado, $2^{\circ}$ Cuando las circunstancias imponen que una prueba se practique ante un juez delegado, éste debe participar después en la decisión de la causa; y, $3^{\circ}$ Si la causa no queda concluida en una audiencia, el órgano colegiado de la audiencia siguiente tiene que estar integrado por las mismas personas, de modo que si ello no es posible la audiencia primera debe reiterarse.

27 Dice Chiovenda, Instituciones, III, Op. cit., p. 162, que forman parte de la documentación "los apuntes que toman los jueces durante la sustanciación de la causan; ya antes, en la conferencia de 1909, había dicho que los jueces deben pronunciarse bajo la impresión de las palabras oídas, pero que ello no excluye que puedan ayudar a su memoria "con apuntes escritos de aquellas declaraciones que no pueden encontrarse en los escritos preparatorios y que tienen importancia para la decisión" (Lo stato attuale, en Saggi, I, p. 415). 
d) Concentración de la sustanciación de la causa en un período único, que se desenvuelva en una audiencia única o en el menor número posible de audiencias próximas.

Decir oralidad es como decir concentración, pues ésta constituye la principal característica exterior del proceso oral, y la misma se refiere tanto a los actos procesales en sí, los cuales deben realizarse en unas pocas audiencias próximas unas a otras, de modo que no se corra el peligro de que las impresiones recogidas en la memoria del juez se borren, como a los incidentes, los cuales deben ser resueltos en la audiencia misma.

e) No pueden impugnarse separadamente las interlocutorias.

Para realizar la oralidad y la concentración se requiere que la decisión sobre incidentes no pueda impugnarse por separado de la cuestión de fondo, de modo que la inapelabilidad de las interlocutorias es una regla de la que no puede prescindirse (salvo en ocasiones muy concretas, como las excepciones litis ingressum impediens).

B) La oralidad y los poderes del juez

Estas eran las notas de la oralidad según Chiovenda y su obra general última. En la misma, después de explicar el principio de la oralidad y las objeciones al mismo, entra a analizar "la oralidad y los poderes del juez», estimando que la oralidad y la concentración procesal son principios íntimamente unidos al problema de los poderes del juez. En la actualidad, dice Chiovenda, por un lado la renovada importancia que ha adquirido el libre convencimiento del juez y, por otro, el concepto renovado de la jurisdicción como función del Estado, han devuelto al juez una posición central de órgano público interesado en administrar justicia del modo mejor y más rápido posible.

Se trata de asegurar al juez una posición que le haga partícipe activo en la relación procesal y proveerle de la autoridad necesaria para ejercer su función. El juez ha de estar en condiciones de dirigir el proceso y conducirlo hasta su resolución con la mayor celeridad posible compatible con una decisión acertada. Además, es conveniente hacerle colaborar en la formación del material de conocimiento, poniéndole en 
contacto inmediato con las partes desde el momento de la constitución del juicio, de forma tal que le sea fácil preparar la sustanciación completa de la causa aclarando las dudas, provocando de las partes las indicaciones más importantes de hecho, señalando de la manera más simple las lagunas que haya en su defensa y en sus pruebas.

El ejercicio de estas facultades sólo es posible en el proceso oral.

A pesar de todo, no está demasiado clara cuál fue la opinión de Chiovenda sobre la relación entre el principio de oralidad y el aumento de los poderes del juez, puesto que cabe recordar como en otro lugar, y en $1924^{28}$, había sostenido que «la oralidad por sí misma no requiere un aumento considerable de la injerencia directiva del juez y no debe identificarse con ésta. Pueden existir procesos orales (como el actual proceso germánico que, desde este punto de vista, representa un tipo de proceso oral opuesto al austríaco) en los que la injerencia del magistrado es mínima. Y se trata de problemas que cuidadosamente han de considerarse distintos, porque el aumento de los poderes del juez puede encontrar por razones de raza y de costumbres dificultades y resistencias mucho más serias y discutibles de aquellas que pueden oponerse a la introducción de la oralidad".

Sobre esos poderes la lectura de las que podemos llamar páginas últimas $^{29}$ ilustra de que Chiovenda se había mantenido dentro del que debe considerarse respeto a la autonomía de la voluntad y a la garantía de los derechos subjetivos de las partes. Una cosa son los poderes del juez para la formación del material de conocimiento, que quedan limitados por el principio dispositivo, en cuanto éste predomina sobre la iniciativa del juez en la fijación de la verdad de los hechos (p. 63); y otra, los poderes del juez respecto de los presupuestos procesales, que sí deben ser controlados de oficio (p. 69), y todo ello aparte del principio de impulso de oficio (p. 71).

28 Chiovenda, "Sul rapporto fra le forme del procedimento e la funzione della prova (L'oralità e la prova)", publicado primero en la Rivista di Diritto Processuale Civile, 1924, I, y después en Saggi, II, Op. cit., pp. 203-204. Este artículo supuso la exteriorización del enfrentamiento con Mortara sobre la oralidad, al que se le imputa que, en su gran Commentario, no había dedicado de modo directo ni un renglón a encaminar la reforma del proceso civil italiano hacia la oralidad (p. 198).

29 Se trata de la p. 54 y siguientes del Tomo III de las Instituciones de Derecho procesal civil, traducción de Gómez Orbaneja, Madrid, 1940. 


\section{El pretendido valor actual de la oralidad}

La idea símbolo puesta en marcha por Chiovenda en el inicio del siglo XX estaba llamada a recibir, durante el curso del mismo, desarrollos que la conducirían muy lejos de sus bases iniciales. Empecemos por recordar dónde no fue recibida a pesar de lo que se dice por el propio legisla dor.

\section{El Codice italiano de 1940}

El 28 de octubre de 1940 la Gazzetta Ufficiale italiana publicó el Codice di procedura civile para entrar en vigor el 21 de abril de 1942. Ninguna de las dos fechas eran casuales. La primera se trataba del dieciocho aniversario de la Marcha sobre Roma y la segunda atendía a una legendaria Fundación de Roma en el más remoto pasado. Al fascismo le gustaban estas demostraciones de grandeza, aunque sean de cartón piedra, de recreación de la historia, a costa de apoderarse del Imperio Romano haciéndolo propio, y de exaltación de los sucesos por él protagonizados.

Para ubicar al Codice en su contexto histórico no está de más recordar que ese mismo día de 28 de octubre de 1940 se produjeron otros acontecimientos que hacen a la historia de Italia. Se trata, por ejemplo, de la entrevista de Hitler con Mussolini en Florencia o de la invasión de Grecia por las tropas italianas. En el mismo día se promulgó el que entonces fue llamado "codice fascista per eccelenza ${ }^{30}$. Ya dentro del mismo Código en la exposición de motivos o Relazione al Re puede leerse que «el Código quiere ser, con decidido conocimiento, expresión histórica del estado fascista y corporativo".

En el Código fascista se presentó como plasmación de las ideas de la oralidad, del aumento de los poderes del juez y de la concentración de la actividad procesal bajo su efectiva guía, ideas que «por el apostolado de Giuseppe Chiovenda habían hecho ya un largo camino" ${ }^{31}$.

30 Así D’Amelio, "Codice fascista», en Corriere della sera, de 27 de octubre de 1940, p. 1, citado por Cipriani, Il Codice di procedura civile, Op. cit., p. 51, y recordando que Mariano d'Amelio, fue primer presidente de la Corte de Casación.

31 Sobre las vicisitudes del "apostolado" en la Relazione al Re, Cipriani, "Piero Calamandrei, la relazione al re e l'apostolato di Chiovenda, primero en Rivista Trimestrale 
Vuelve a aparecer, ahora no la propaganda, pero sí el apostolado. Lo peor del caso es que el Código y la Relazione no pueden calificarse de chiovendianos o lo son sólo en la apariencia.

A pesar de que se ha estimado, pues, que el Codice de 1940 era chiovendiano y no fascista, y que en él se asumió el pensamiento chiovendiano sobre la oralidad, ello no es cierto. El nombre del Maestro se utilizó para justificar la concepción publicista del proceso, es decir, aquello que hace que el Código tenga base ideológica fascista ${ }^{32}$,

di Diritto e Procedura Civile, 1997 y después en Ideologie e modelli, Op. cit., pp. 7073. En el original de la Relazione, redactada por Calamandrei, aparecía una referencia expresa al apostolado de Chiovenda que fue suprimida por Grandi, por lo que en el texto de aquélla, aparecido en la Gazzetta Ufficiale, no figuraba; hay que esperar a que la misma Gazzetta, ahora el 16 de abril de 1941, publicara la corrección de erratas, la más importante de las cuales es la relativa a la inclusión de la frase relativa al apostolado de Chiovenda (en el apartado 3 [Precedentes de la reforma], párrafo 5 , a la mitad).

32 Se puede leer en esa Relazione: «Si el Código de 1865 fue, por razones históricas que quizá ni siquiera fueron advertidas por sus autores, expresión de las premisas individualistas que estaban en la base del Estado liberal, el Código de 1940 quiere ser, con conocimiento decidido, expresión histórica del Estado fascista y corporativo. El fortalecimiento del principio de autoridad del Estado se proyecta y se traduce necesariamente, en el proceso, en un fortalecimiento de la autoridad del juez; fortalecimiento, con todo, que no se reduce a un simple aumento de los poderes de un órgano del Estado, ni a una ampliación de la injerencia de éste en las relaciones de la vida privada y en la esfera de los derechos individuales del ciudadano, sino que es expresión de un cambio de perspectiva en la valoración de los intereses tutelados y garantizados por el derecho.

En el Estado fascista el proceso no es solamente el encuentro de la libertad del ciudadano con la autoridad del Estado, provocado por la necesidad de tutelar los intereses del primero; ni es el puro expediente formal para regular el conflicto de los intereses privados y para terminar el litigio entre sus titulares. El Estado fascista no niega los intereses privados, sino que antes al contrario reconoce la importancia de los mismos como impulsores de iniciativas privadas y por tanto los tutela; y no existe verdadera tutela de intereses que no se refleje en un fuerte sistema procesal. Pero esta tutela no es un fin en sí misma, pues no existe, en nuestro ordenamiento, interés que no sea tutelado en función de su valor social y, en definitiva, de los superiores intereses de la nación. Por tanto, en el Estado fascista el proceso no es sólo lucha de intereses, sino instrumento para la composición fecunda de los mismos y, sobre todo, instrumento para asegurar, no sólo un ordenado sistema de vida social, inspirado en los supremos fines del Estado, sino también para asegurar, por medio de la aplicación de las normas jurídicas que regulan la vida de la nación, la realización en las relaciones 
y desde luego en el Código no se asumió la concepción chiovendiana de la oralidad.

Lo que destaca más claramente en el Código, incluso a primera vista, es la figura del juez instructor, que es algo típicamente italiano y desconocido en otros países. La figura misma no está claramente perfilada en sus orígenes ${ }^{33}$, pero lo que nos importa es que la existencia misma del juez instructor es contraria a la oralidad, en el sentido explicado por Chiovenda, pues para éste era esencial que las pruebas se practicaran precisamente delante del tribunal en su conjunto, de todos los magistrados que tenían que valorarlas, y no simplemente ante uno de los integrantes del órgano colegiado, se llamara a ese juez delegado $o$ instructor.

Pero no se trata sólo de la oralidad; se trata de que la base ideológica del Código, que es y no podía ser de otra manera fascista, no era la de Chiovenda, por mucho que éste participara de una concepción en buena medida autoritaria y no liberal de las relaciones entre Estado e individuo. Chiovenda se ha había mostrado en desacuerdo con Menger, hablando de la necesidad de ser más prudente ${ }^{34}$, aunque no puede desconocerse que se ha llegado a afirmar que es un precursor del fascismo ${ }^{35}$.

En cualquier caso no puede olvidarse, por lo que diremos después, que incluso Calamandrei sostuvo, no ya en la Relazione al Re, de la que es autor, sino en obra científica propia y con autoría reconocida públicamente, que «el nuevo Código habría podido, teóricamente, adoptar

privadas de los intereses supremos de ésta. Y, sobre todo, es instrumento para realizar lo que la palabra del Duce ha indicado como meta de la Revolución fascista: una más alta justicia social».

33 La paternidad de la idea ha sido discutida; véase Cipriani que la considera «incierta" en Il Codice di procedura civile, Op. cit., p. 27, nota 62.

34 Anton Menger, que era el apóstol del socialismo jurídico, publicó dos obras importantes, en lo que nos afecta, Il Diritto civile e il proletariato, Torino, 1894, traducción de Oberosler, y Lo stato socialista, Milano, 1949, traducción de Olberg. Según su concepción todos los procesos en el futuro debían adoptar las formas del proceso de oficio. En esa línea, por ejemplo, Cappelletti, "Ideologie del diritto processuale», en Processo e ideologie, Bologna, 1969, p. 17 y ss., y Denti, La giustizia civile, Bologna, 1989 , p. 26 y ss.

35 Tarello, "L'opera di Giuseppe Chiovenda nel crepuscolo dello stato liberale", en Dottrine del processo civile, coordinados por Guatini e Rebuffa, Bologna, 1989, p. 181 y ss. 
el sistema propio del proceso penal, consistente en introducir el absoluto imperio del impulso de oficio, desvinculando el mecanismo procesal, una vez puesto en movimiento, de cualquier otra injerencia de las partes ${ }^{36}$. Por este incierto camino acabará diciendo algún discípulo que el Código dio pocas facultades al juez civil.

\section{Del valor actual de la idea símbolo de la oralidad}

Con esos orígenes el paso del tiempo iba a dar muchas sorpresas en la determinación de lo que debía entenderse por oralidad, siempre partiendo de que la misma no comportaba sólo la realización de actos orales en el proceso, sino de que se había convertido en una manera de aludir a todo un modelo de proceso civil. La sorpresa más grande es la que proporciona Cappelletti ${ }^{37}$, el cual iba a elevar la oralidad a idea símbolo.

\section{A) La oralidad y la prueba}

De entrada se llega a afirmar que para Italia y para los países de lengua española la oralidad significa, sí un amplio programa de reformas procesales, pero, sobre todo, se trataba ya de que por proceso oral se asume un doble significado: «de proceso más rápido, concentrado y eficiente, y de proceso más fiel a una metodología concreta y empírico-inductiva en la búsqueda de los hechos y en la valoración de las pruebas»" ${ }^{38}$. El amplio programa de reformas procesales comprendía:

a) La abolición de todos los arcaicos residuos del sistema de prueba legal.

Es cierto que cuando se habla de abolición de estos residuos se centra la atención en el juramento decisorio vinculante para el juez

36 Piero Calamandrei, Istituzioni di Diritto processuale civile, I, Padova, 1943, p. 212.

37 Citamos por Mario Cappelletti, La oralidad y las pruebas en el proceso civil, Buenos Aires, 1972 (traducción de Sentís Melendo), pero no deben olvidarse Processo e idelogie, Bologna, 1969, y Giustizia e società, Milano, 1972.

38 Mario Cappelletti, "Proceso oral y proceso escrito", en La oralidad y las pruebas, Op. cit., pp. 76-78. 
(que no es un medio de prueba), en el interrogatorio escrito y formal de las partes, en la prohibición del testimonio de las partes y de los terceros interesados, y similares, pero, en cualquier caso, lo pretendido es que desaparezcan todos los residuos de la prueba legal, siendo sustituidos por un sistema de valoración de las pruebas dejado a la apreciación crítica del juez.

b) La inmediación de las relaciones entre el órgano decisor (juez único o colegio) y los elementos de convicción.

Esta inmediación del juez con las partes, testigos, peritos, lugares y cosas, se concibe únicamente como la atmósfera necesaria para un sistema de libre admisión y de valoración "crítica" de las pruebas. En la concepción de Cappelletti no hay alusión a que la inmediación suponga la necesidad de que sea uno mismo el juez que práctica la prueba y el que dicta la sentencia, atendiéndose a esa otra finalidad sobre admisión y valoración de la prueba, que es algo nuevo.

c) La sustanciación oral de la causa en una audiencia única o en pocas audiencias próximas.

La finalidad de esta única o audiencias próximas es no perder, a causa de un proceso diluido en el tiempo, las ventajas de la inmediación de la relación entre el juez y los elementos de prueba, y ello sin perjuicio de la preparación de esa audiencia por medio de escritos.

\section{B) La socialización de la justicia}

Lo más llamativo, con todo, es el segundo significado que se atribuye a la oralidad, significado que consiste en una progresiva socialización del derecho en general y del proceso en particular. En este campo los países socialistas (los de entonces, los de 1970) ${ }^{39}$ se presentan como modelo, si bien empezando por resaltar que la idea tiene su origen en Klein, «genial autor» del código austríaco de 1895, el cual ya partía de que el proceso civil es un instrumento para el bienestar social ${ }^{40}$.

39 La ponencia "Proceso oral y proceso escrito" se presentó al "VIII Congreso Internacional de Derecho Comparado", celebrado en Pescara en 1970.

40 Esta es una las sorpresas que da la memoria histórica. Klein y la Ordenanza austríaca de 1895 representan una concepción autoritaria del Estado y del proceso, la que es propia del imperio austro-húngaro de finales del siglo XIX, de ideología esen- 
El juez, en esta concepción, asume un cometido de guía y de propulsión procesal, no solamente técnica y formal (controlando la observancia de las reglas del fair play y el ordenado y rápido desarrollo del procedimiento), sino también material; desde el mismo inicio del proceso asume un cometido de carácter activo y asistencial respecto de las partes, buscando con ellas la verdad para que al final, la victoria sea de la parte que tiene razón y no de aquélla que sepa prevalecer en virtud de su mayor fuerza económica o por la mayor habilidad de su defensor. Se acaba de este modo -se dice- con la vieja concepción del juez neutral, que era algo puramente formal.

En este ejercicio de palabrería política las cosas llegan hasta el extremo de admitir, con los pseudo juristas comunistas de la época de Stalin, que la oralidad se resuelve así en un fenómeno de democratización de la justicia y del proceso civil. La oralidad -sigue diciendo Cappellettitiene en los países socialistas una importancia y una base jurídico-política absolutamente particulares, entre otras cosas porque permite al juez asumir una función social que se manifiesta en el papel activo del juez en la búsqueda de la verdad material; un proceso socialista se caracteriza esencialmente porque, reflejando siempre intereses de orden público y no meramente privados, entiende que no puede dejarse el proceso mismo a merced de los acuerdos, o del descuido o de la ignorancia o también de la desigualdad dialéctica de las partes ${ }^{41}$.

cialmente reaccionaria (Sprung, "Le basi del diritto processuale civile austriaco», en Rivista di Diritto Processuale, 1979, y Cipriani, "Nel centenario del Regolamento di Klein (Il processo civile tra libertà e autorità)", en Ideologie e modelli, Op. cit., p. 27 y ss.), y a pesar de ello su influencia en Cappelletti es tan manifiesta que su libro Processo e idelogie, Op. cit., se coloca bajo una frase - lema de Klein. No debe olvidarse que en la base de Klein estaba el control de los jueces por el poder ejecutivo y, más aún, el apoderarse de la justicia, también de la civil, que debía colocarse al servicio del interés general, siempre bien advertido que ese interés general es el que el poder político dice que es y en cada momento; el juez no es así el último garante de los derechos de los ciudadanos, sino el servidor de los intereses de la sociedad, y el titular de turno del poder es el que determina cuáles son esos intereses. No puede dejar de destacarse que Cappelletti, "Proceso oral y proceso escrito", en La oralidad y las pruebas en el proceso civil, $O p$ cit., p. 81, acababa por sostener que la oralidad requería una "gran magistratura: un juez honesto, socialmente sensible, diligente", que es -afirma- el juez austríaco que ha asegurado el éxito del código de Klein.

41 En el fondo se trata de convertir al proceso civil en algo parecido a la jurisdicción voluntaria, en la que el juez asume una función no jurisdiccional, sino de tutela 
De este modo y con esta base ideológica se termina pretendiendo que el proceso moderno sólo puede ser oral, pero que la oralidad sólo puede entenderse en el sentido que se acaba de exponer.

\section{El replanteamiento del sentido de la oralidad}

No creo que haga falta insistir en que el pretendido valor actual del principio de oralidad había llevado a la mezcla caótica de cosas distintas, produciendo una confusión que no tenía salida lógica, salvo la de aclarar distinguiendo entre lo que atiende a la forma de los actos procesales y lo que se refiere al contenido de los mismos o, si se prefiere, entre procedimiento y proceso. De la misma manera no hace falta insistir en que hoy no puede seguir manteniéndose que la oralidad lleve inevitablemente a un "proceso social", en el sentido en que esa expresión se ha entendido en los países ex socialistas, entre otras cosas porque ese proceso se basaba en la inexistencia de verdaderos derechos subjetivos privados de ámbito civil, es decir, en la supresión de la autonomía de la voluntad privada, lo que se resolvió de modo muy claro en la falta de libertad. Cuando en los países occidentales se hablaba de "proceso social» y por verdaderos juristas, se estaba pretendiendo decir algo muy distinto de lo que entendían los juristas comunistas utilizando la misma expresión.

Hay que empezar por replantearse lo que puede suponer hoy la oralidad, y hay que hacerlo aclarando, de entrada, que el principio se refiere a la forma, al procedimiento, no al proceso, al contenido de los actos procesales.

\section{Proceso y procedimiento}

Los llamados "procedimientos judiciales» consistieron en el siglo XIX en describir la previsión legal respecto de los actos que debían realizar

de los particulares, a los cuales se les considera poco menos que menores o incapacitados. Baste recordar que esto era lo pretendido por Baumbach, magistrado nazi en 1938, por Menger, el apóstol del socialismo jurídico a finales del siglo XIX, y por autores comunistas de todo el siglo XX, los cuales auspiciaron la desaparición de las varias clases de procesos, sobre todo el penal y el civil, para acabar en una única manera de actuar el derecho en el caso concreto: de oficio por el juez. 
las partes y el órgano jurisdiccional, y así la procédure era el conjunto de formas que los ciudadanos debían seguir para obtener justicia y que los tribunales habían de observar para otorgarla. Procedimiento, en este sentido histórico, equivale a la forma. El paso dado por los procesalistas consistió, precisamente, en percatarse de que limitándose a describir las distintas formas procedimentales, reduciéndose a la descripción del desarrollo temporal de los distintos procedimientos, no se estaba haciendo ciencia, que lo importante era darse cuenta de la calidad jurídica de lo que hacían las partes y el juez, de que era preciso hallar un sistema que abarcara la variedad de formas ${ }^{42}$. Surgió así la noción de proceso; en éste lo importante no era ya la forma.

Junto a la distinta manera de entender la disciplina, según se llamara "procedimientos judiciales" o "derecho procesal», las diferencias entre proceso y procedimiento se manifiestan en que:

1) El término procedimiento no es exclusivo del ámbito judicial, sino que es aplicable — refiriéndonos exclusivamente a su contenido jurídico - a todas las funciones del Estado, y así se habla de procedimiento legislativo y, sobre todo, administrativo (existe una ley de procedimiento administrativo, pero no puede existir una ley que regule el proceso ante la administración).

2) Procedimiento, pues, hace referencia a forma, a sucesión de actos, y ello sin precisar si esa actividad es la de los órganos jurisdiccionales, pues puede ser también la de los órganos administrativos.

3) Cuando se habla de procedimiento judicial se está destacando la forma de la actividad judicial, el «lado extremo de la actividad procesal ${ }^{43}$, "una consideración meramente formal del proceso" ${ }^{44} \mathrm{o}$ "el fenómeno de la sucesión de actos en su puro aspecto externo» ${ }^{45}$, la mera actividad o sucesión de actos en el tiempo.

4) Aunque proceso y procedimiento tienen una misma raíz etimológica, procedere, en el segundo destaca la nota de actuación externa, el

42 Sobre la evolución que arranca de la práctica forense para llegar al Derecho jurisdiccional, puede verse Juan Montero, Derecho Jurisdicción. I, Parte General, $10 .^{a}$ edición (con G. Colomer, Montón y Barona), Valencia, 2000, p. 13 y ss.

43 Prieto-Castro, Tratado de derecho procesal civil, I Pamplona, 1985, p. 51. 44 Gómez Orbaneja, Derecho procesal civil, I, Madrid, 1976 (con Herce), p. 14 45 De la Oliva, Derecho procesal civil, I, Madrid, 1995 (con Fernández), p. 132. 
trabajo que pudiéramos llamar administrativo que se realiza en cualquier actividad jurídica y, por tanto, también en ésta, mientras que en el primero es necesario tomar en consideración la estructura y los nexos que median entre los actos, los sujetos que los realizan, la finalidad a que tienden, los principios a que responden, las condiciones de quienes los producen, las cargas que imponen y los derechos que otorgan. Mientras existe procedimiento en cualquier actividad jurídica, el proceso es propio y exclusivo de la actuación jurisdiccional.

Con base en lo dicho puede llegarse a las siguientes conclusiones: 1 . La función jurisdiccional se ejerce sólo a través del proceso; 2. Jurisdicción y proceso son realidades correlativas e interdependientes, sin proceso no hay ejercicio de la función jurisdiccional; 3 . Todo proceso se desarrolla formalmente a través de un procedimiento; 4. Existen procedimientos judiciales que no son la forma externa de un proceso (en aquellos casos en que el juez no actúa jurisdiccionalmente); y, 5. Un solo procedimiento judicial puede ser la forma externa de dos o más procesos.

\section{La forma de los actos procesales}

En nuestra opinión todo el problema del procedimiento, de la forma, puede resumirse en dos principios: oralidad y escritura, aclarando inmediatamente que cuando nos referimos a la oralidad incluimos dentro del principio aquellos otros que se derivan de él, es decir, inmediación, concentración y publicidad, y lo mismo con los principios contrarios derivados; de la escritura.

Desde el inicio hay que dejar bien sentado, por evidente, la imposibilidad práctica de configurar un procedimiento de manera totalmente oral o escrita. De ahí que no se trate de exclusividades sino de prevalecimientos. Resulta así que el problema de los principios de oralidad o de escritura es un problema de límites. Si en un procedimiento escrito la palabra ha de ser la forma de realización de algunos actos procesales, y si de un procedimiento oral la escritura no puede estar totalmente ausente, todo se reduce a determinar cuándo, por prevalecer una forma $\mathrm{u}$ otra, podemos correctamente decir que estamos ante un procedimiento oral o escrito. 
Tradicionalmente el elemento base para diferenciar un procedimiento oral de otro escrito se ha centrado en la manera de aportar las partes los hechos al proceso y de formular la pretensión; resultaba así que se atendía, no a un conjunto de caracteres, sino a un único elemento, y sin perjuicio de que luego de ese carácter se desprendieran otros en consecuencia.

En este sentido se habían pronunciado autores fundamentales, y así Chiovenda ${ }^{46}$, partiendo de la imposibilidad de configurar un procedimiento totalmente oral, hablaba de proceso mixto, precisando que éste sería predominantemente oral o escrito atendiendo al momento de aportación de los elementos fácticos por obra de las partes, es decir, de la interposición de la pretensión con su fundamentación correspondiente; allí donde la pretensión ha de ser presentada necesariamente en forma escrita, estamos ante un proceso escrito, aunque las partes tengan la posibilidad de ilustrar oralmente el contenido de los escritos. De aquí la distinta manera como operan los escritos de uno y otro procedimiento; en la escritura son la forma de las deducciones, mientras que en la oralidad los escritos son meramente preparatorios, anuncio de las deducciones que se van a hacer en la audiencia y medio básico para poner al demandado en situación de defenderse.

Más recientemente en España Prieto-Castro ${ }^{47}$ ha persistido en esta línea, diciendo que el principio de oralidad determina que (salvo algunas excepciones) únicamente lo que de palabra se aporte al proceso puede ser valorado por el juez y tenido en cuenta en la resolución final; y la presencia del otro principio, el de escritura, significa que tan sólo (salvo algunas excepciones) lo aportado de esta forma puede producir esos resultados, y para significarlo así viene empleándose el brocardo quod non est in actis non est in mundo.

La doctrina que calificamos de tradicional, junto a lo anterior, destacó que con las palabras oralidad y escritura sintetizaba un conjunto de caracteres del procedimiento, un sistema completo de principios inseparables los unos de los otros, pero en todo caso quedaba claro que la oralidad significaba en primer lugar y principalmente, que la preten-

46 Chiovenda, Instituciones, III, Op. cit., p. 159 y ss.

47 Prieto-Castro, «Precisiones sobre escritura y oralidad», en Estudios y comentarios para la teoría y la práctica procesal civil, I, Madrid, 1950, p. 100. 
sión había de formularse oralmente, y que por escritura había de entenderse que la pretensión se realizaba por escrito.

En la actualidad centrar la oralidad y la escritura en un único elemento como base imprescindible nos parece unilateral, y estimamos que no puede hacerse depender de él la naturaleza del procedimiento. Este será oral o escrito atendiendo a un conjunto de principios, en los que, junto a la forma oral o escrita de los actos procesales, hay que resaltar otros de tanta o mayor importancia. La oralidad y la escritura son dos modos de hacer el procedimiento, el conjunto del mismo, no la forma de un único acto procesal.

\section{La oralidad en la nueva LEC española}

Reducida la oralidad a la determinación de la forma de los actos procesales, sin que con ella se atienda al contenido de los actos, debemos examinar ahora cuáles son los elementos que la caracterizan realmente y que son los que se han asumido en el nuevo proceso regulado en la Ley de Enjuiciamiento Civil española de 2000, pues en ella se dispone un procedimiento oral, pero en el sentido estricto de la expresión, no en el desbordado por el mito.

\section{A) Forma oral de los actos procesales}

Naturalmente el principio de oralidad significa, en primer lugar, que en los actos procesales predomina lo hablado sobre lo escrito, como medio de expresión y comunicación entre los diferentes sujetos que intervienen en el proceso. Hoy no cabe admitir que el momento típico para distinguir entre un procedimiento oral y otro escrito sea el de las deducciones de las partes. Esto conduciría a que un proceso civil en el que la demanda y la contestación se hicieran por escrito, pero en el que todos los demás actos fueran orales, habría de ser calificado de escrito. Lo importante no es ya el modo de alegar los hechos a los que debe estar el órgano judicial, sino el conjunto de la actividad procedimental, de los actos del proceso.

El predominio del acto procesal oral no puede impedir la existencia de actos escritos, sea cual fuere el contenido de éstos, pero en todo caso lo paradójico es que probablemente este elemento es el que menos sirve para caracterizar un procedimiento de oral y de ahí la 
importancia de los siguientes. En efecto el predominio de la oralidad no puede atender a que un o unos pocos actos determinados se realicen de modo oral, sino al conjunto de la actuación, y ello sin atender principalmente al contenido de esos actos.

Si hubiera que destacar algo que normalmente caracteriza al procedimiento oral diríamos que esta clase de procedimiento suele acabar con una audiencia oral en la cual el juez se pone en relación directa con las pruebas personales (testigos y peritos) y con las partes, sin perjuicio de que esta audiencia haya sido preparada por una serie de actos escritos, en los cuales incluso puede haberse interpuesto la pretensión.

Este es precisamente el esquema del procedimiento regulado en la nueva LEC de $2000^{48}$. La demanda y la contestación se realizan por escrito, y en ellas se determina el objeto del proceso y el objeto del debate (sin que después quepan modificaciones sustanciales), se realiza después una audiencia previa con función especialmente saneadora (procesal), pero también delimitadora de los términos del debate (material), para acabar convocándose a un verdadero juicio oral, en el que se practicará toda la prueba.

\section{C) Inmediación}

La oralidad implica, en segundo lugar, inmediación, es decir, la exigencia de que el juzgador se haya puesto en contacto directo con las demás personas que intervienen en el proceso, sin que exista entre ellos elemento alguno interpuesto. Esta exigencia es particularmente importante con relación a las pruebas, hasta el extremo de que normalmente se ha venido concibiendo la inmediación solamente como la exigencia de que el juez que ha de pronunciar la sentencia haya asistido a la práctica de las pruebas.

La inmediación es parte esencial del procedimiento oral, tanto que puede afirmarse que no se trata de principios distintos y autónomos, sino que son dos aspectos de una misma realidad.

48 En el texto nos vamos a referir sólo al llamado juicio ordinario de la LEC, puesto que el llamado juicio verbal no tiene duda alguna de naturaleza de procedimiento oral. Este juicio verbal sigue siendo el inicialmente creado en 1534 para los asuntos de pequeña cuantía, que ha sido pasando por todas las reformas posteriores. 
Uno de los efectos de la inmediación es la imposibilidad de que se produzcan cambios en las personas físicas que componen el órgano jurisdiccional durante la tramitación de la causa, y en especial que sólo pueden concurrir a dictar la sentencia los magistrados ante los que se ha desarrollado la audiencia oral en la que el juez o tribunal se pone en relación directa con las pruebas y con las partes.

En los procedimientos españoles de tipo oral la inmediación es una consecuencia. En el nuevo proceso civil se ha tenido el acierto de no llevar la inmediación y su consecuencia a sus últimos extremos. La regla general es la de que el juez que debe dictar sentencia ha de haber practicado la prueba, y de ahí la necesidad de que presida el juicio oral y dicte sentencia un mismo juez, lo que supone también que en ese juicio debe practicarse toda la prueba, pero ello no impide la posibilidad de que: 1) En algún caso pueda practicarse prueba entre la audiencia previa y el juicio oral, sin que sea necesario que la presida el mismo juez que luego efectuará el juicio y dictará la sentencia, y 2) Excepcionalmente se acuda a la práctica de la prueba por auxilio judicial, esto es, practicando algún medio de prueba con un juez distinto al que está conociendo del proceso y en lugar distinto al de celebración del juicio oral.

La inmediación es lo normal, pero el legislador español no ha querido llevar el principio a sus últimas consecuencias, admitiendo posibles excepciones al mismo, excepciones que dependen del juez que conoce del proceso en su aplicación concreta.

\section{C) Concentración}

Decir oralidad es también decir concentración, y lo es tanto que se ha sostenido que lo que caracteriza a un procedimiento oral es más la concentración que la mera oralidad de los actos procesales ${ }^{49}$.

Con relación a la actividad procedimental, que es lo que ahora nos interesa, la concentración supone que los actos procesales deben desarrollarse en una sola audiencia, o en todo caso en unas pocas audiencias próximas temporalmente entre sí, con el objetivo evidente de que las manifestaciones realizadas de palabra por las partes ante el juez y las

49 Alcalá-Zamora, "Proceso oral y abogacía", en Estudios de teoría general e historia del proceso (1945-1972), II, México, 1974, p. 17 y 19. 
pruebas permanezcan fielmente en la memoria de éste a la hora de dictar la sentencia. El ideal de todo procedimiento es la concentración en una sola audiencia de todos los alegatos de las partes, de la proposición y práctica de la prueba e incluso de la resolución del asunto, y que si este ideal es difícilmente conseguible, la tarea del legislador y del tribunal consiste en aproximar lo más posible el procedimiento al ideal.

La influencia de la concentración sobre la forma del proceso es evidente, y de ahí que haya sido considerado la principal característica exterior del proceso oral. Al mismo tiempo se ha señalado su influencia sobre la brevedad de los pleitos, frente a la escritura que supone necesariamente dispersión de los actos procesales en el tiempo. De aquí que se haya dicho, por Alcalá-Zamora, que si las mayores ventajas del procedimiento oral obedecen al principio de concentración, sería preferible hablar de proceso concentrado en vez de proceso oral. Con todo, lo que importa es tener en cuenta que la concentración no es sin más una consecuencia de la oralidad.

La concentración se asume todo lo posible en el proceso civil regulado en la Ley 1/2000, de Enjuiciamiento Civil. En el juicio ordinario existen dos «audiencias», la llamada previa, que tienen funciones de saneamiento de óbices procesales y de delimitación del debate, y el llamado juicio, en el que deben practicarse todas las pruebas, con lo que se trata ya únicamente del tema de fondo del proceso.

\section{D) Publicidad}

Por último, la oralidad supone necesariamente publicidad, entendida ésta en su verdadera significación.

Cuando se habla del principio de publicidad suele distinguirse entre publicidad para las partes y publicidad general, pero se trata de una distinción que carece de sentido ${ }^{50}$. La llamada publicidad para las partes se refiere en realidad al principio de contradicción o audiencia, pues si un acto procesal fuera secreto para las partes no se estaría haciendo referencia a la forma del proceso, al procedimiento, sino que se estaría colocando a aquéllas en situación de indefensión. La verdadera publicidad, la

50 Para esta distinción por ejemplo Chiovenda, Instituciones, III, Op. cit., p. 201. Correctamente, Fairén, "Ideas y textos sobre el principio de publicidad del proceso", en Temas del ordenamiento procesal, I, Madrid, 1969. 
que aquí consideramos, es la que se refiere al público, y respecto de ella afirmamos su carácter político y su dependencia de la oralidad.

Ya es sintomático que en las constituciones y en los textos internacionales más importantes se haya recogido la garantía de la publicidad del proceso. Así lo ha hecho también el Art. 120.1 de nuestra Constitución declarando que "las actuaciones judiciales serán públicas, con las excepciones que prevén las leyes de procedimiento". Esta declaración por sí misma sería inútil por no añadir nada a la situación precedente y porque, al remitir las excepciones a las leyes ordinarias, sin establecer en la propia Constitución los criterios fundamentales que hacen admisible una excepción, está estableciendo un principio vacío de contenido. Para darle utilidad hay que poner en relación el Art. 120.1 con el Art. 24.2 de la propia Constitución (derecho a un proceso público), con el Art. 14.1 del Pacto Internacional de Derechos Civiles y Políticos de 1966 y con el Art. 6.1 de la Convención de Salvaguardia de los Derechos del Hombre y de las Libertades Fundamentales de 1950 , en donde se establece que las excepciones tienen que justificarse en intereses que, desde el plano constitucional, merezcan protección preferente a la publicidad (vid. STC 62/1982, de 15 de octubre).

Sin oralidad no hay publicidad. En un procedimiento escrito las normas legales pueden establecer la publicidad, pero son normas de imposible cumplimiento en la práctica. Sólo un proceso oral y concentrado permite la publicidad y con ella la fiscalización popular del funcionamiento de la justicia.

Cuando se habla de publicidad el principio debe acomodarse a los tiempos. Hoy no tiene sentido decir que la publicidad permite que el público entre en el local de la audiencia para presenciar la realización del acto procesal; en la actualidad la publicidad no puede dejar de atender a los medios de comunicación social (prensa, radio, televisión) y ha de entenderse que proceso público es aquél al que pueden tener acceso esos medios, los cuales se constituyen como una especie de "representantes" del público, y como tales tienen todos los derechos del "público», pero no más. De la misma manera el derecho de las partes a un proceso público no cabe entenderlo hoy desconectado de los medios de comunicación social.

La nueva LEC, limitándose en esto a mantener una conquista del siglo pasado, dispone en su Art. $138^{\circ}$ que las actuaciones de prueba, las vistas y las comparecencias, cuyo objeto sea oír a las partes antes de 
dictar una resolución, se practicarán en audiencia pública, con lo que establece que todas las actuaciones orales han de ser públicas.

\section{La vía de los procesos plenarios rápidos}

Una ley o, mejor, un código, con 827 artículos que pretende expresar y materializar, con autenticidad, el profundo cambio de mentalidad que entraña el compromiso por la efectividad de la tutela judicial civil, no puede quedar resumida en unas pocas páginas, siendo necesario su estudio completo para llegar a percatarse de lo que realmente significa. Ahora bien, como es necesario hacer un esfuerzo de síntesis, conviene empezar por decir que lo verdaderamente importante en la LEC no son los aspectos de detalle, por mucho que vengan impuestos por los tiempos que corren (como sería el que las actuaciones orales en vistas y comparecencias se registren en soporte apto para la grabación y reproducción del sonido y de la imagen), pues esos detalles no hacen a la esencia del cambio de modelo procesal pretendido. Es la pretensión de introducir un nuevo modelo de proceso civil lo que hace que estemos ante una LEC nueva y no, simplemente, ante una reforma y actualización de la vieja.

Las leyes de enjuiciamiento civil de 1855 y de 1881 se limitaron a asumir como juicio tipo el proceso ordinario del Derecho común y, en torno al mismo, se redactaron completamente. En ellas los juicios plenarios rápidos se consideraron meras excepciones, reservadas para pocos asuntos y éstos de poca importancia cuantitativa. La nueva LEC supone, por fin, la ruptura con aquel proceso ordinario y toda ella se centra en dos juicios plenarios rápidos. Independientemente de las palabras se trata de los ahora llamados juicio ordinario (Libro II, Título II) y juicio verbal (Libro II, 'Título III). Después de siete siglos el modelo del proceso común ha sido abandonado.

La idea de que el proceso requiere «fórmulas lentas, graves, solemnes, complicadas y rigurosas a que el orden judicial debe sujetarse en el ejercicio de sus funciones y que son garantía de seguridad para los litigantes y prenda de acierto en los fallos", que fue la defendida por el Colegio de Abogados de Madrid en sus Observaciones a la Instrucción del marquéz de Gerona ${ }^{51}$, podía tener sentido en un contexto social de

51 Se trata de las «Observaciones sobre la Instrucción del procedimiento civil de 
tipo rural en el que los pleitos tenían como objeto la propiedad y, sobre todo, la de la tierra, para los que el tiempo no era un elemento trascendente. Esa idea es la que está en base de las dos leyes de enjuiciamiento civil del siglo XIX y es la que se ha abandonado en la nueva LEC.

El problema fundamental del proceso civil en las últimas décadas ha sido el del aumento de la litigiosidad, que suele presentarse como un mal cuando es sólo un síntoma de profundas modificaciones sociales. En efecto:

1. Durante siglos el proceso civil fue el instrumento con el que los poseedores solucionaban sus litigios, de modo que los no poseedores quedaban excluidos del mismo. Sólo determinadas capas de la población tenían acceso a este proceso, lo que suponía un número no excesivo de procesos que podían ser solucionados por una organización judicial reducida y con pocos medios personales y materiales.

2. En muy poco tiempo, prácticamente en los últimos cincuenta años, han accedido a la justicia civil amplias capas de la población que antes estaban excluidas de ella, en parte porque el número de propietarios ha aumentado, pero también porque otros derechos han entrado en liza, como es el caso de la responsabilidad extracontractual $y$, sobre todo, porque se han convertido en objeto principal de este proceso las reclamaciones de dinero basadas en el crédito.

Hoy el proceso civil no es ya el medio para solucionar los conflictos típicos de una sociedad rural, sino el instrumento con el que se tiene que hacer frente a los conflictos propios de una sociedad urbana y así este proceso se ha convertido en un fenómeno de masas, en el que el elemento fundamental del mismo es su efectividad práctica. Si se lee la Exposición de Motivos de la LEC se advertirá que su idea base es la de la efectividad de la justicia civil.

La efectividad era algo ajeno al modelo proceso de la LEC de 1881 $\mathrm{y}$ hoy tiene que ser el eje sobre el que gira el modelo procesal de la nueva LEC. Esa finalidad es la que justifica que el modelo procesal sea el de los juicios plenarios rápidos.

30 de septiembre de 1853", publicadas en la Revista General de Legislación y de Jurisprudencia, 1854, tomo 3, pp. 13-92, y redactadas por una comisión integrada por la Junta de Gobierno del Colegio de Abogados con la asistencia de los ex decanos. 
El solemnis ordo iudiciarius ha muerto después de una vida casi tan larga como la de Matusalén y ha triunfado el tipo de proceso que apareció como excepcional. Este triunfo no se manifiesta simplemente en la supresión de unos trámites y en la abreviación de unos plazos. Se expresa fundamentalmente en la idea de adecuación del proceso a la realidad de este tiempo y en que, por fin, el legislador ha osado acabar con un sistema que ya no era producto de la razón natural y respecto del que el prestigio entre algunos juristas era producto del conservadurismo acrítico. Natural no puede dejar de existir quien en el entierro se conduela de esta muerte, la califique de temprana y aun manifieste su desconfianza en el nuevo modelo procesal considerándolo prematuro. Siempre ocurre de este modo; siempre existe quien se conduele de la desaparición del pasado.

El nuevo modelo es, por tanto, el del proceso plenario rápido y sus caracteres esenciales siguen siendo el de intentar adecuarse a la realidad. Se basa así en la oralidad del juicio ordinario, para el que se dispone que las pruebas deben practicarse en un único acto concentrado y con inmediación. Oralidad, inmediación, concentración y publicidad son las notas del proceso civil español.

\section{Sección Tercera}

Los principios del nuevo proceso civil español (o además de la oralidad)

\section{$\mathrm{X}$. Los principios generales}

Partiendo de que el principio de oralidad atiende única y exclusivamente a la forma de los actos procesales, y no a la conformación del proceso y de sus principios configuradores, es necesario aludir a estos otros principios para acabar dando una idea de lo que ha supuesto la nueva Ley de Enjuiciamiento Civil española de 2000. En ella se ha optado por los procesos plenarios rápidos, pero ello no ha supuesto alterar la base ideológica liberal, que parte de la existencia de derechos subjetivos privados que se ejercen en libertad. 


\section{El principio de oportunidad y el sistema económico}

El sistema procesal civil encuentra su apoyo ideológico en la concepción liberal de la sociedad, que se manifiesta principalmente en el aspecto económico, en la distinción entre intereses públicos e intereses privados. En el proceso civil el interés que la parte solicita que sea protegido o tutelado por el órgano jurisdiccional es privado, siendo preponderante en él la autonomía de la voluntad. El titular de ese interés es el individuo, no la sociedad y, por tanto, se trata de un derecho o interés disponible. La distinción entre derecho público y derecho privado es fundamental y también el que el proceso civil es el instrumento destinado a la satisfacción o tutela de intereses privados.

La diferente naturaleza de los intereses en juego presupone la existencia de dos tipos de procesos. Frente a un proceso necesario, en el que por tratarse de intereses públicos el principio de necesidad determinará su nacimiento y contenido, ha de existir otro proceso en el que, por tratarse de intereses privados, la voluntad de las partes es el elemento determinante tanto de su nacimiento como de su contenido y extinción. Estos dos modelos básicos se corresponden con los procesos penal y civil; en el primero predomina el interés público, siendo su realización necesaria; en el segundo lo determinante para la iniciación del mismo es la voluntad del individuo, el cual, atendiendo a razones de oportunidad, acudirá o no al proceso para la defensa de sus intereses ${ }^{52}$.

La conformación del proceso civil se encuentra, pues, en el régimen económico que se asuma en la Constitución. A la vista de los arts. $33^{\circ}$

52 En los países con régimen comunista las cosas habían sucedido de muy distinta manera. En éstos se negaba la distinción entre intereses públicos y privados y, por tanto, la razón principal de ser de una regulación del proceso civil distinta de los otros tipos de proceso. Frente a una concepción liberal de la economía, en la que prácticamente todo es privado, se estableció un sistema radicalmente opuesto. En frase de Lenin: «No reconocemos nada privado; para nosotros todo el campo de la economía reviste carácter de derecho público y no de privado". La consecuencia fue la desaparición de la libertad, pero en lo que nos importa ahora que el proceso civil se sujetara a principios propios de la necesidad. La frase de Lenin la citamos por Gurvich, Derecho procesal civil soviético, México, 1971, traducción de Lubán, p. 44, el cual sigue diciendo que la desaparición de la distinción entre lo público y de lo privado conduce a la desaparición de la principal razón de ser de una reglamentación del proceso civil distinta de la de los otros tipos de proceso. 
y $38^{\circ}$ de la Constitución española, principalmente, creemos indudable que hay que partir del reconocimiento de la distinción entre intereses privados y públicos. El Art. $33^{\circ}$ reconoce el derecho a la propiedad privada, y éste es uno de los pilares del principio de oportunidad en el proceso civil, hasta el extremo de que puede afirmarse, con razón, que si el proceso penal gira en torno al derecho a la libertad, el proceso civil lo hace sobre el de propiedad. El fundamento del derecho de propiedad reside, aparte del goce de la cosa, en que el propietario pueda decidir libremente el destino económico que a la cosa quiere dar, lo que implica autonomía de la voluntad. El que hoy a este derecho no se le atribuya carácter absoluto, el que venga limitado su contenido por ley, atendida su función social, no puede suponer desvirtuación de su esencia.

Por otra parte, el Art. $38^{\circ}$ comienza por reconocer la libertad de empresa, situando además este derecho «en el marco de la economía de mercado». La interpretación de la primera proposición de este artículo requiere tener en cuenta dos elementos de juicio: 1) Cuando el artículo habla de que "reconoce», o de que se "garantizan y protegen" (en presente de indicativo), nos quiere indicar que admite como válido el sistema económico existente en el momento de promulgarse la Constitución, y 2) La expresión economía de mercado tiene hoy un sentido admitido de manera indudable, refiriéndose al sistema liberal capitalista de organización económica. Como ocurre en el caso anterior, también aquí existen matizaciones, recogidas principalmente en los artículos $128^{\circ}$ y siguientes (los relativos a Economía y Hacienda), pero no alteran el principio básico de la iniciativa económica de los particulares.

Resulta así que la Constitución española se asienta en una concepción que reconoce a los particulares la disposición de sus intereses, su autonomía de la voluntad, su libertad para decidir tanto que relaciones jurídicas materiales contraen como la mejor manera de defender los derechos subjetivos que tienen, y de ahí se deriva el principio de oportunidad. Este principio es el determinante de toda la regulación posterior del proceso civil, aunque no venga previsto de modo expreso en la Ley de Enjuiciamiento Civil, la cual se refiere a los principios que se derivan del mismo y, especialmente, al principio dispositivo. 


\section{El principio dispositivo}

Tradicionalmente dentro del principio dispositivo se han venido confundiendo dos principios distintos, aunque complementarios: el principio dispositivo en sentido estricto ( $o$ Dispositionsmaxime), esto es, la disponibilidad que las partes tienen sobre el interés privado y la conveniencia o no de acudir al órgano jurisdiccional pretendiendo su satisfacción y, en segundo lugar, el principio de aportación de parte (o Verhandlungsmaxime), por el que las partes tienen también el monopolio de aportar al proceso los elementos de hecho y los medios de prueba ${ }^{53}$.

Advertida esa confusión, hay que deslindar claramente los dos principios. El dispositivo se fundamenta en la naturaleza privada del derecho subjetivo deducido en el proceso, en la titularidad particular del mismo, en la autonomía de la voluntad de los ciudadanos y, en definitiva, en la libertad. Como decía Calamandrei el deducir un derecho en vía jurisdiccional es un modo de disponer del mismo y, por consiguiente, el condicionar la tutela jurisdiccional a la petición del interesado es una consecuencia lógica de la autonomía negocial reconocida al particular sobre su propia esfera jurídica ${ }^{54}$. Partiendo de este fundamento el principio debe significar:

1) La actividad jurisdiccional sólo puede iniciarse ante petición de parte; el particular debe ser libre para medir el interés que le mueve a luchar por su derecho o a dejarlo ignorado o insatisfecho.

2) La determinación concreta del interés cuya satisfacción se solicita de los órganos jurisdiccionales es facultad exclusiva de las partes o, en otras, palabras, la determinación del objeto del proceso corresponde al actor mediante la pretensión y la determinación del objeto del debate al demandado por medio de la resistencia.

3) Los órganos jurisdiccionales al satisfacer, por medio del proceso y de la sentencia, intereses privados, deben ser congruentes con la pretensión y la resistencia formuladas.

53 Carnacini, "Tutela giurisdizionale e tecnica del processo", en Studi in onore di Redenti, II, Milano, 1951; existe traducción española de Romo en Revista de la Facultad de Derecho de México, octubre-diciembre de 1953, $\mathrm{N}^{\circ} 12$.

54 Piero Calamandrei, Istituzioni, I, Op. cit., pp. 213-216. 
4) Si las partes son las únicas que pueden incoar la actividad jurisdiccional, pueden también ponerle fin, disponiendo del interés o intereses cuya satisfacción se solicitaba.

El principio dispositivo así configurado informa y debe seguir informando al proceso civil y así lo asume la nueva LEC española, como lo dice expresamente en su Exposición de Motivos. Y ello, naturalmente, sin perjuicio de que puedan irse matizando aquellos casos de irrenunciabilidad de derechos que la defensa de intereses, tanto colectivos como particulares, haga necesarios, y también aquellos otros de ejercicio abusivo o antisocial, para lo que ya se cuenta, por ejemplo, con los arts. $6^{\circ}$ y $7^{\circ}$ del Código Civil, y el Art. 11.2 Ley Orgánica del Poder Judicial. Y sin perjuicio también, lógicamente, de regular un proceso civil no dispositivo, referido principalmente al estado civil y condición de las personas.

\section{La llamada publicización del proceso}

El principio dispositivo determina quién inicia el proceso y también indica que son las partes quienes fijan su objeto, pero a partir de aquí es preciso atender a cómo deben repartirse las facultades materiales y procesales en la dirección de ese proceso.

En la concepción propia del siglo XIX se partía de la idea de que la naturaleza privada de los intereses en juego en el proceso civil debía significar que las partes tenían que ser también las «dueñas del proceso». Esta idea proviene de la desconfianza del liberalismo frente a toda actividad del Estado y ahora, en concreto, frente a los órganos jurisdiccionales del mismo. Estos en esa concepción están al servicio de los particulares para solucionar, cuando y como aquellos juzguen conveniente, los conflictos de intereses. De ahí la limitación extraordinaria de las facultades del juez en el proceso regulado en el siglo XIX; Manresa, el autor principal de la Ley de Enjuiciamiento Civil española de 1881, consideraba que «la mejor ley de procedimientos es la que deja menos campo al arbitrio judicial», por cuanto este arbitrio «es incompatible con las instituciones liberales" ${ }^{55}$.

55 Manresa, Comentarios a la Ley de Enjuiciamiento Civil, I, 1. ${ }^{\text {a }}$ edición, Madrid, 1881 , p. 10. 
Frente a la idea de que el proceso es "cosa de las partes", a lo largo del siglo XX se ha ido haciendo referencia a la llamada publicización del proceso, estimándose que esta concepción arranca de Klein y de la Ordenanza Procesal Civil austríaca de 1895. Las bases ideológicas del legislador austríaco, enraizadas en el autoritarismo propio del imperio austro-húngaro de la época y con extraños injertos, como el del socialismo jurídico de Menger, pueden resumirse, como han destacado Sprung ${ }^{56}$ y Cipriani ${ }^{57}$, en estos dos postulados: 1) El proceso es un mal, dado que supone una pérdida de tiempo y de dinero, aparte de llevar a las partes a enfrentamientos con repercusiones en la sociedad, y 2) El proceso afecta a la economía nacional, pues impide la rentabilidad de los bienes paralizados mientras se debate judicialmente sobre su pertenencia. Estos postulados llevan a la necesidad de resolver de modo rápido el conflicto entre las partes, y para ello el mejor sistema es que el juez no se limite a juzgar sino que se convierta en verdadero gestor del proceso, dotado de grandes poderes discrecionales, que han de estar al servicio de garantizar, no sólo los derechos de las partes, sino principalmente los valores e intereses de la sociedad.

A partir de Klein puede seguirse toda una evolución en la que, de una u otra forma, se destaca una pretendida función social del proceso, su conversión en un fenómeno de masas, en torno al que se consagra la expresión publicización del mismo, y sobre la que la doctrina ha debatido y sigue debatiendo. En ese debate se ha llegado a sostener la conveniencia de suprimir el principio de la iniciación del proceso a instancia de parte, como se hizo en los países comunistas.

Naturalmente señalar que el Estado está interesado en el mejor desarrollo del proceso civil es algo obvio, y lo es tanto que no ha sido negado por nadie, pero desde esta obviedad no puede llegarse en el razonamiento posterior a la conclusión de negar la plena aplicación del principio dispositivo, pues ello implicaría negar la misma existencia de la naturaleza privada de los derechos subjetivos materiales en juego. La publicización del proceso tuvo su origen en un momento y en un país determinado y se plasmó en una Ordenanza Procesal Civil que, al menos,

56 Sprung, "La basi del diritto processuale civile austriaco", en Rivista di Diritto Processuale, 1979, p. 27.

57 Cipriani, "Nel centenario del Regolamento de Klein", en Ideologie e modelli, Op. cit., pp. 29-30. 
debe calificarse de antiliberal y autoritaria, y opuesta a su alternativa que es la concepción liberal y garantista del proceso civil. El conceder amplios poderes discrecionales al juez, y precisamente a unos jueces como el austríaco o el italiano de sus épocas fuertemente sujetos al poder ejecutivo, sólo se explica si al mismo tiempo se priva de esos poderes a las partes, poderes que en realidad se resuelven en garantías de las mismas en el inicio y en el desarrollo del proceso civil ${ }^{58}$.

No se ha destacado lo suficiente que los códigos en que se han concedido mayores facultades a los jueces se han promulgado precisamente en países y momentos en que esos jueces eran menos independientes, de lo que ha resultado que, a la postre, con la concesión de esas facultades se estaba favoreciendo la injerencia del poder ejecutivo en la efectividad de los derechos subjetivos de los ciudadanos.

Una cosa es reconocer que el proceso civil ya no es sólo el reducto de la clase media de un país, es decir, el medio previsto por el legislador para que los poseedores debatan en torno al derecho de propiedad, y otra muy distinta configurarlo como un fenómeno de masas en el que no importan tanto los derechos individuales del ciudadano cuanto los intereses públicos o sociales. Por ello en los últimos años estamos asistiendo a la difusión de la idea de que el proceso civil se resuelve básicamente en un sistema de garantías de los derechos de los ciudadanos, en

58 La Relazione al Re del Codice italiano de 1940 proclamaba paladinamente que el aumento de los poderes del juez era "direttiva fondamentale della riforma" (12, párrafo 1): «El juez [...] es el órgano al que el Estado confía la función esencial de actuar la ley por medio del procedimiento. En el fondo de la cuestión está el renovado concepto de la dignidad y autoridad del Estado fascista y de sus órganos, por lo que no sería concebible que el juez asista, espectador impasible, y tal vez impotente, como si fuese un árbitro en un campo de gimnasia que se limita a asignar puntos y a controlar que sean observadas las reglas del juego, a una lucha en la que se empeña, por el contrario, la más celosa y la más alta función y responsabilidad del Estado. Es necesario, por tanto, que el juez tenga la dirección del proceso, una posición preeminente y reguladora". La Relazione había sido olvidada, después de no haber sido publicada desde 1943 (así Cipriani, Codice di procedura civile con la Relazione al Re, Bari, 1997), pero los que tenían edad para haberla leído en su día han ocultado que la reiterada alusión que después se ha hecho a juez espectador y a juez director provenía de ella. Cuando en la actualidad se sigue sosteniendo por muchos, que el juez no puede seguir siendo un mero espectador del proceso se están repitiendo las palabras que Calamandrei puso en la pluma de Grandi, y se está afirmando que el aumento de los poderes del juez es una conquista de la civilización (se entiende fascista). 
el medio jurídico para que las partes debatan en condiciones de plena contradicción e igualdad los conflictos que los separan. Y ello sin dejar de asumir la realidad social de la proliferación de los procesos y de la búsqueda de nuevas soluciones y, sobre todo, sin confundir la autonomía de la voluntad y la libertad de los ciudadanos en la tutela de sus derechos e intereses legítimos y el hacer posible esa tutela de modo efectivo, facilitando el acceso a los tribunales y tendiendo a que dicho acceso se realice en condiciones de igualdad.

El fenómeno de la publicación se ha basado, creemos, en una gravísima confusión entre las facultades materiales y las facultades procesales de dirección del proceso ${ }^{59}$. Una cosa es aumentar los poderes del juez respecto del proceso mismo (en su regularidad formal, en el control de los presupuestos procesales, en el impulso, por ejemplo) y otra aumentarlas con relación al contenido del proceso y de modo que pueda llegarse a influir en el contenido de la sentencia. No hay obstáculo alguno en aumentar las facultades procesales ( $\mathrm{y}$ de ahí que nadie se oponga a convertir el tradicional impulso de parte en impulso de oficio), y con ello puede entenderse que se prima al interés público sobre el privado, pero sí lo hay en que el juez pueda de oficio iniciar el proceso o alegar hechos o practicar prueba no pedida por las partes, pues de este modo se está afectando a la existencia de los derechos subjetivos reconocidos en la norma material.

\section{Las facultades materiales de dirección}

El reparto de las facultades materiales de dirección del proceso entre el juez y las partes atiende a quién debe aportar los elementos que pueden influir en la decisión que ha de adoptar el juez al final del mismo. Esos elementos se refieren a los hechos y a las pruebas, y a ellos atiende el llamado principio de aportación.

59 Carreras, «La función del juez en la dirección del proceso civil (Facultades materiales de dirección)", en Estudios de Derecho Procesal (con Fenech), Barcelona, 1962; Fenech, "Facultades procesales de dirección", en el mismo volumen. Serra, "Liberalización y socialización del proceso civil», en Revista de Derecho Procesal Iberoamericana, 1972, 2.3; Cordón, "En torno a los poderes de dirección del juez civil", en Revista de Derecho Privado, 1969. 


\section{La aportación de los hechos}

Respecto de los hechos el principio de aportación significa que corresponde a las partes la facultad de dirección que se refiere a que los hechos han de ser afirmados por las partes, pues a ellas se atribuye la determinación del objeto del proceso y del objeto del debate. El juez no puede aportar hechos al proceso. El Art. $216^{\circ}$ de la nueva LEC dice que los tribunales civiles decidirán los asuntos en virtud de las aportaciones de hechos y pretensiones (en realidad, peticiones) realizadas por las partes.

\section{A) El objeto del proceso}

Prescindiendo ahora de los elementos subjetivos de la pretensión (de quien pide y de frente a quien se pide, es decir, del demandante y del demandado), los elementos objetivos de esa pretensión son lo que se pide (o petitum) y la causa de pedir (la causa petendi). El principio dispositivo supone que el juez debe ser congruente con lo que se pide por las partes, pero también que no puede tener en cuenta más que los hechos aducidos como causa de pedir de esa petición. ${ }^{60}$

La individualización de la pretensión, es decir, el distinguirla de todas las demás posibles, consta de dos elementos:

1. $\left.{ }^{\circ}\right)$ Subjetivos: Las partes del proceso, quien formula la pretensión (actor o demandante) y aquél contra el que se formula (demandado).

2..$^{\circ}$ Objetivos: Son lo que se pide y la causa de pedir. La petición determina el objeto del proceso civil porque, tratándose de derechos subjetivos privados, el demandante tiene completa libertad para fijar lo que pide.

El demandante puede fijar, primero, la clase de tutela jurisdiccional que pide (declaración, constitución o condena) y, después, el bien concreto que pide, mientras que el demandado puede admitir la petición

60 Ya respecto de la LEC de 2000, Tapia Fernández, El objeto del proceso. Alegaciones. Sentencia. Cosa juzgada, Madrid, 2000. 
allanándose a ella. El juez puede pronunciarse sólo sobre lo que se pide y queda vinculado por las admisiones hechas por el demandado.

La causa de pedir son siempre hechos, acontecimientos de la vida que suceden en un momento en el tiempo y que tienen trascendencia jurídica, esto es, que son el supuesto de una norma que les atribuye consecuencias jurídicas. Esos hechos han de ser aportados en todo caso por el demandante, pues de lo contrario se estaría destruyendo uno de los pilares del principio dispositivo y con él de la autonomía de la voluntad y de la libertad de los particulares para ejercitar los derechos subjetivos que cada uno estima que le son propios.

El proceso civil se basa en que sólo el demandante puede aportar los hechos que fijan la causa de pedir del proceso civil. La parte es así la única que puede decidir si acude al proceso (por el ejercicio del derecho de acción) y la única que decide los términos de la pretensión que ejercita; elemento determinante de esa pretensión es lo que pide y el porqué lo pide; ese porqué han de ser hechos y los mismos sólo puede aportarlos la parte. El juez no puede tener nunca la facultad de aportar hechos al proceso para determinar la causa de pedir de la petición, y tampoco podrá apartarse de esa causa de pedir a la hora de estimar o desestimar la pretensión.

\section{B) El objeto del debate}

Frente a la pretensión del demandante, el demandado, al formular su resistencia, puede limitarse a negar los hechos afirmados por aquél, pero también puede afirmar hechos que sirvan de fundamentación a su resistencia y petición de absolución. Los hechos afirmados por el demandado no servirán para determinar el objeto del proceso (que es siempre y sólo la pretensión), pero sí sirven para:

1. $\left.{ }^{\circ}\right)$ Ampliar los términos del debate: Si el demandado fundamenta su resistencia, esto es, si alega hechos propios, esos hechos amplían la materia sobre la que se debate en el proceso.

2.o) Completar lo que debe decidirse en la sentencia: Si el demandado alega hechos propios, la decisión del juez no puede ya referirse sólo a la pretensión del demandante (petición y fundamentación), sino que ha de atender también a la fundamentación de la resistencia. 
Todos los hechos, tanto los que sirven de causa de pedir de la petición del actor, como los que fundamentan la resistencia del demandado, tienen que ser aportados al proceso por las partes. El juez no puede delimitar, mediante aportaciones propias de hechos, ni el objeto del proceso, ni el objeto del debate.

Si el juez pudiera aportar hechos atentaría a la misma esencia de lo que es un proceso civil, pues con ello se estaría convirtiendo en parte. Suele decirse que esta imposibilidad de aportación de hechos por el juez se basa en la imparcialidad del mismo, de modo que si llegara a admitirse esa aportación se convertiría en parcial. En realidad lo que impide esa aportación no es el principio de imparcialidad del juez, sino la existencia de funciones o papeles incompatibles en el proceso. En éste cada uno de los sujetos que intervienen en él tiene un papel que cumplir y la mezcla de esos papeles llevaría a que el juez, bien adoptara el papel de parte (si investigara los hechos para aportarlos), bien asumiera el papel de testigo (si ha tenido conocimiento de los mismos extrajudicialmente). Juez y parte y juez y testigos son papeles incompatibles.

\section{C) El tema de prueba}

La distinción anterior entre objeto del proceso y objeto del debate precisa completarse atendiendo al tema de prueba (no al objeto de la prueba, que es cosa diferente), esto es, a lo que debe probarse en un proceso concreto para que el juez declare la consecuencia jurídica pedida por la parte. El tema de prueba son:

1. $\left.{ }^{\circ}\right)$ Los hechos afirmados por una o por otra parte: la prueba ha de referirse a los hechos afirmados por el actor, pero también a los hechos afirmados por el demandado, cuando éste no se ha limitado a negar la fundamentación de la petición del actor, sino que ha efectuado afirmaciones propias de hechos. La prueba sólo puede referirse a esos hechos; si un hecho no ha sido afirmado al menos por una de las partes, ese hecho no existe para el proceso.

2. $\left.{ }^{\circ}\right)$ Los hechos controvertidos: dentro de los hechos afirmados por las partes, la necesidad de prueba sólo puede referirse a los hechos que, después de las alegaciones, resulten controvertidos. Los hechos afirmados por las dos partes, o afirmados por una y admitidos por la otra, han de ser estimados como existentes por el juez, el cual no podrá desconocerlos en la sentencia. 
El principio de aportación de parte supone también que éstas tienen la facultad de admitir como existentes los hechos afirmados por la contraria, quedando los mismos fijados para el juez, que ha de partir de su existencia a la hora de dictar sentencia, sin que pueda desconocerlos. Si las partes delimitan el objeto del proceso y el objeto del debate, esto es, si pueden afirmar los hechos que estimen conveniente para fundamentar su pretensión y su resistencia, no puede negarse estas otras consecuencias: 1) Los hechos no afirmados al menos por una de las partes no existen, y 2) Los hechos afirmados por las dos partes, o afirmados por una y admitidos por la otra, existen.

Esto es lo que se dice en el Art. $281^{\circ}$ de la LEC cuando, por un lado y en apartado 1, se dispone que la prueba tendrá por objeto los hechos que guarden relación con la tutela pedida en el proceso y, por otro, el apartado 3, declara exentos de prueba los hechos sobre los que exista plena conformidad de las partes (salvo cuando el objeto del proceso no fuera disponible).

\section{La determinación del derecho aplicable}

Los antiguos brocardos iura novit curia y da mihi factum dabo tibi ius ponen de manifiesto el deber y facultad del juez, primero, de conocer el derecho y, segundo, de aplicar en el caso concreto que juzga la norma adecuada. Esta facultad y deber no esta sujeta a discusión doctrinal y no lo está porque la normas jurídica no sirve para delimitar el objeto del proceso.

Los anteriores brocados tienen su origen en los glosadores (no son romanos) y sirven también para poner de manifiesto la distinta posición del juez ante los hechos y ante el derecho. Un hecho no afirmado al menos por una de las partes no existe para el juez y un hecho afirmado por las dos partes existe para el juez; por el contrario, el juez no puede dar por existente una norma aducida por las dos partes si esa norma realmente no existe, y no puede dejar de tomar en cuenta una norma existente, aunque no haya sido aducida por las partes. Las normas existen o no independientemente de que las partes las aduzcan y la conformidad entre ellas no puede crearlas.

Normalmente en el proceso civil las normas reguladoras de la demanda disponen que en la misma el actor realizará una fundamentación en derecho de lo que pide, y lo mismo se ordena para la contestación 
de la demanda al demandado, aunque no siempre es así. Cuando se trata de procesos relativos a asuntos de escasa entidad económica, en los que no se exige la intervención de abogado, las leyes permiten la presentación de demandas y de contestaciones a la demanda sin fundamentación jurídica, y esto sólo es porque esa fundamentación no añade nada a la individualización del objeto del proceso y porque el juez debe aplicar la norma que legalmente corresponda.

La alegación de una norma general y abstracta (un determinado artículo del Código Civil, por ejemplo) no puede servir para distinguir un proceso civil de otro, para individualizarlo, y de ahí que suela entenderse que «los Tribunales no tienen ni necesidad ni obligación de ajustarse, en los razonamientos jurídicos que les sirven para motivar sus fallos, a las alegaciones de derecho de las partes, y pueden basar sus decisiones en fundamentos jurídicos distintos, pues a ello les autoriza la regla del aforismo iura novit curia” (STC 20/1982, de 5 de mayo).

Siendo esto lo normal en los supuestos ordinarios (el actor pide que se condene al demandado a pagarle una cantidad, afirma unos hechos determinados y dice que los mismos dieron lugar a una relación jurídica de permuta, con cita de un artículo del Código Civil, el juez puede condenar a esa cantidad diciendo en la sentencia que la relación jurídica lo fue de compraventa y cita otro artículo del Código Civil), no falta algún supuesto en lo que la situación se presenta de modo no tan evidente. Lo que debe tenerse en cuenta en cualquier caso es que la regla no puede llegar a la negación del principio dispositivo, esto es, no puede conducir a entender que el juez puede condenar a lo no pedido por la parte, a más de lo pedido o a basarse en razones distintas de las aducidas por la parte.

Por eso dispone el Art. 218.1, II que el tribunal, sin apartarse de la causa de pedir acudiendo a fundamentos de hecho o de Derecho distintos de los que las partes hayan querido hacer valer, resolverá conforme a las normas aplicables al caso, aunque no hayan sido acertadamente citadas o alegadas por los litigantes.

Cosa distinta es que el cambio del punto de vista jurídico pueda llegar a entenderse como indefensión de las partes, que no han podido conocer ni alegar en torno al mismo. La "tercera opinión", la del juez, ha de haberse puesto antes en conocimiento de las partes, dando a éstas la oportunidad real de alegar sobre la misma. Lo que entra en juego entonces no es el objeto del proceso, sino el derecho de defensa. 


\section{Las facultades procesales}

La dirección formal del proceso atiende a quién asumirá en el mismo las facultades de controlar la regularidad o formal o técnica de los actos procesales y de impulsar el procedimiento para que éste se desarrolle pasando de una fase a otra. En otras palabras, la dirección formal no se refiere ni afecta al contenido del proceso; afecta al proceso en sí mismo considerado y básicamente ha de resolver quién, si el juez o las partes: 1) Debe controlar la admisibilidad de la pretensión y, por tanto, si es posible dictar o no una sentencia de fondo al concurrir los presupuestos necesarios para ello (no el contenido de la sentencia, sino su misma existencia), y 2) Debe impulsar el proceso haciéndolo avanzar por la fases previstas legalmente.

Las facultades procesales no se refieren a aquello que puede servir para determinar el contenido de la sentencia, sino sólo a aquello que puede determinar, primero, si hay sentencia sobre el fondo (presupuestos procesales) y, después, cuando y como se llega a la sentencia (impulso procesal).

\section{Sobre los presupuestos procesales}

La teoría de los presupuestos procesales tiene su origen en Oscar von Bülow que, partiendo de la consideración del proceso como relación jurídica, los concebía como «elementos constitutivos de la relación jurídica procesal», esto es, como las prescripciones que deben fijar «la admisibilidad y las condiciones previas para la tramitación de toda relación procesal». Un defecto en cualquiera de ellos impediría el surgir del proceso ${ }^{61}$. Los presupuestos se refirieron así a todo el proceso y condicionaban la existencia del mismo.

El paso siguiente consistió en poner de manifiesto que la amplitud con que se entendían era excesiva. Los presupuestos se refieren sí a todo el proceso, pero no pueden ser condicionantes de la existencia del proceso mismo, pues si los presupuestos se examinan y se resuelve sobre su

61 Oscar Von Bülow, La teoría de las excepciones procesales y los presupuestos procesales, Buenos Aires, 1964 (el original alemán es de Giesse, 1868), traducción de Rosas, pp. 4 y ss. y 292 y ss. 
existencia en el proceso, es que ya ha existido éste. Por eso Goldschmidt y Rosenberg refirieron los presupuestos a la sentencia sobre el fondo.

Los presupuestos atienden a condiciones que, si bien referidas al proceso como conjunto y no a actos procesales determinados, lo que condicionan es que en el proceso pueda llegar a dictarse una resolución sobre el fondo del asunto. El órgano judicial puede haber tramitado todo el proceso para advertir, en el momento de dictar sentencia, que en ésta no puede decidir sobre la pretensión planteada ante la falta de alguna de esas condiciones.

Bülow, siempre concibiendo el proceso como relación de Derecho público, entendía que la validez de la relación procesal es una cuestión que no puede dejarse a la voluntad de las partes, al no ser una cuestión privada, sino que el control de la existencia de los presupuestos puede realizarse por el juez de oficio. No se trata de que los controle sólo el juez, sino que él puede hacerlo si las partes no oponen las oportunas excepciones procesales.

Advertido, con todo, que no ocurre así en todos los ordenamientos jurídicos se distinguió por Rosenberg ${ }^{62}$ entre:

1) Presupuestos: que son aquellos que un ordenamiento jurídico permite que sean controlados de oficio por los órganos jurisdiccionales, e

2) Impedimentos: los que han de ser alegados por alguna de las partes (lógicamente por el demandado) para que puedan ser tenidos en cuenta por el juez.

Las condiciones determinan, en todo caso, la posibilidad de que el juez pueda dictar una sentencia sobre el fondo del asunto, pero el que en un ordenamiento jurídico existan más presupuestos que impedimentos, o viceversa, depende de como en ese ordenamiento se han repartido las facultades entre el juez y las partes en general o respecto de cada proceso concreto. La vieja concepción del siglo XIX llevó a que en la regulación del proceso civil el juez tuviera pocas facultades de control de los presupuestos procesales, de modo que existían más impedimentos procesales; conforme se han ido dictando leyes nuevas las

62 Rosenberg, Tratado de derecho procesal civil, II, Buenos Aires, 1955, traducción de Romera Vera, pp. 44 y ss. 
facultades del juez han ido aumentando y con ellas su control de los presupuestos ${ }^{63}$.

En la LEC de 2000 el aumento de las facultades del juez sobre los presupuestos procesales se manifiesta en que, en la audiencia previa, puede proceder de oficio al control de todos los presupuestos procesales. Según el Art. 416.1 el tribunal resolverá en la esa audiencia sobre cualesquiera circunstancias que puedan impedir la válida prosecución y término del proceso mediante sentencia sobre el fondo.

Un aspecto concreto del control de los presupuestos procesales es el relativo a la inadmisión in limine o inicial de la demanda, pues debe tenerse en cuenta que una cosa es que el juez controle en ese momento la concurrencia de los presupuestos (determinando cuáles son insubsanables y cuáles subsanables) y otra que pueda inadmitir la demanda por razones de fondo.

Es evidente que el juez ha de poder no admitir a trámite una demanda cuando él no es competente por razón de la materia para conocer de la misma, pero también lo es que en el inicio del proceso el juez no puede atender a las posibilidades de éxito de la pretensión interpuesta en ella. La regla general ha de ser que el juez ha de admitir todas las demandas, pues en ello está en juego el derecho de acción, constituyendo la inadmisión la forma más clara de indefensión. La decisión del juez sobre la admisión de la demanda puede atender a la concurrencia de los presupuestos y al cumplimiento de los requisitos procesales, pero no a la cuestión de fondo, a si la pretensión tiene o no posibilidades de éxito (salvados supuestos excepcionales).

63 Aunque no siempre se manejan con suficiente precisión los términos, no es lo mismo decir presupuesto procesal que requisito procesal. Si los primeros se refieren a todo el proceso, los segundos atienden actos procesales en concreto. Ante la falta de un presupuesto (o impedimento) el juez no puede dictar sentencia de fondo; ante la falta de un requisito se producirá la ineficacia de un acto determinado. La confusión proviene de que en ocasiones la determinación de la concurrencia de los presupuestos tiene que realizarse en momentos iniciales, bien del proceso bien de algún recurso, esto es, sin esperar a llegue el de dictar sentencia, y entonces puede llegarse a la inadmisión de ese acto inicial, no por la falta de un requisito sino por la de un presupuesto. El ejemplo más claro es el de la demanda, que puede ser inadmitida por el juez ante la falta del presupuesto de la competencia que, evidentemente, se refiere a todo el proceso, y que no consiste en que falta un requisito de la demanda misma como acto. 


\section{Sobre el impulso procesal}

La alternativa entre el impulso de parte y el impulso oficial no se refiere a quién inicia el proceso y ni siquiera a en manos de quién queda la iniciativa para continuarlo por medio de los recursos o de la ejecución, pues a todo ello atienden principios ya examinados.

La iniciación del proceso depende siempre del principio dispositivo, por lo que corresponde a las partes. También son éstas las que pueden o no interponer recursos contra las resoluciones dictadas, sin que exis$\tan$ recursos de oficio. De la misma manera la ejecución de la sentencia se iniciará siempre previa petición de parte (Art. $549^{\circ}$ LEC de 2000).

Cuando se habla del impulso se está haciendo referencia a quién, las partes o el juez, hace avanzar el proceso dentro de una instancia o dentro de la ejecución; el impulso, pues, presupone que las instancias o la ejecución ya se han iniciado, a petición de parte, y atiende a los pasos que han de darse dentro de cada una de ellas. En el impulso de parte el proceso avanza a instancia de parte, pues son éstas las que deben solicitar del juez que declare terminada una fase procesal y que abra la siguiente, mientras que cuando rige el impulso de oficio el juez dicta las resoluciones precisas para hacer avanzar el proceso sin esperar a que exista petición de parte ${ }^{64}$.

En la actualidad el impulso oficial rige en todos los procesos por cuanto se ha entendido que ha de quedar dentro de las facultades del órgano jurisdiccional, presupuesta la incoación bien en virtud del principio dispositivo bien del de oficialidad, el hacer que el proceso se desarrolle por sus fases normales. Adviértase, con todo, que el impulso no se refiere a la continuación del proceso por medio de los recursos y de la ejecución, que siempre exigen petición de parte.

En el proceso civil español el paso de un acto procesal a otro dependía de la petición de las partes. El Art. $521^{\circ}$ de la LEC de 1881, en su redacción originaria, dejaba completamente en manos de las partes el impulso procesal: "Transcurrido el término señalado a una parte para cualquier traslado, actuación o diligencia sin haberlo evacuado y, en su caso, la prórroga que se hubiese otorgado, a instancia de la contraria, se dará a los autos el curso que corresponda». Estábamos aquí ante una 
consecuencia inevitable de la ideología liberal y del predominio de las partes en el proceso.

La situación se hizo insostenible y a remediarla vino el RD-ley de 2 de abril de 1924 , que derogó los arts. $308^{\circ}, 309^{\circ}, 311^{\circ}, 312^{\circ}$ y $521^{\circ}$ de la LEC, introduciendo el impulso oficial: "No será necesario que los litigantes insten el curso del procedimiento, una vez iniciado, para que las autoridades del orden judicial observen y hagan observar, sin excusa alguna, en toda clase de juicios y actuaciones de que conozcan los términos procesales señalados al efecto" (Art. $\left.1^{\circ}\right)^{65}$. Después la Ley $34 /$ 1984 , de 6 de agosto, derogó este RD-ley pero introduciendo sus normas de la LEC de 1881.

La LOPJ de 1985 llevó a su Art. $237^{\circ}$ la regla general de que, salvo que la ley disponga otra cosa, el órgano jurisdiccional dará de oficio al proceso el curso que corresponda dictando los proveídos necesarios, y en el Art. $288^{\circ}$ confió ese impulso al secretario judicial por medio de las diligencias de ordenación. Ahora el Art. 179.1 de la LEC de 2000 establece que, salvo que la ley disponga otra cosa, el órgano jurisdiccional dará de oficio al proceso el curso que corresponda dictando las resoluciones necesarias y el Art. $216^{\circ}$ añade que la falta de impulso del procedimiento por las partes o interesados no originará la caducidad de la instancia o del recurso.

\section{Los principios relativos a la prueba}

Tradicionalmente la función de la prueba ha venido refiriéndose al descubrimiento de la verdad, dándose así origen a otro mito ahora en materia de prueba, y con más profundas consecuencias prácticas que en el anterior.

\section{La pretendida búsqueda de la verdad}

En este sentido de la búsqueda de la verdad se pronunció toda la doctrina del siglo XIX y también buena parte de la del presente, para la que «las pruebas son los diversos medios por los cuales llega la inteli-

65 Sentís Melendo, "Celeridad en los juicios", en Teoría y práctica del proceso, III, Buenos Aires, 1959, p. 58 y ss. 
gencia al descubrimiento de la verdad ${ }^{66}$. Sin pretender plantear cuestiones metafísicas (la verdad a la que se llega por la inteligencia), físicas (la verdad que proporcionan los sentidos) o históricas (la verdad que nos narran otras personas) puede afirmarse que hoy se reconoce comúnmente que esa aspiración era demasiado ambiciosa. La humildad ha exigido acabar con este otro mito.

\section{A) La renuncia a la verdad}

La necesidad de renunciar a la búsqueda de la verdad se descubre simplemente teniendo en cuenta algo que es consustancial con el proceso civil:

a) Los hechos no afirmados al menos por una de las partes no existen para el juez, que no puede salir a la búsqueda de los mismos.

b) Los hechos afirmados por las dos partes o afirmados por una y admitidos por la otra existen para el juez, que no puede desconocerlos en la sentencia.

c) Respecto de los hechos controvertidos debe recordarse que la actividad probatoria no es investigadora, sino simplemente verificadora, lo que supone que:

1. ${ }^{\circ}$ En sentido estricto la investigación implica ir a la búsqueda o descubrimiento de unos hechos desconocidos y, evidentemente, éste no es el supuesto del proceso civil; en él las partes tienen la facultad exclusiva de realizar las afirmaciones de hechos y el juzgador se limita a verificar la exactitud de esas afirmaciones y, además, sólo en el caso de que hayan sido negadas o contradichas. Únicamente respecto de los hechos controvertidos ha de producirse la verificación o comprobación.

2. $\left.{ }^{\circ}\right)$ Los elementos con los que debe producirse la verificación no son los que decida discrecionalmente el juzgador, sino los que propongan las partes. En otros ordenamientos jurídicos, los basados en una concepción autoritaria del juez, éste puede

66 Bonnier, Tratado teórico-práctico de las pruebas en derecho civil y penal, I, Madrid, 1869, traducción de De Vicente y Caravantes, p. 48. 
decidir, sin petición de parte, la práctica de medios de prueba, pero en el Derecho español, de raigambre liberal y garantista, sólo se practicarán los medios que propongan las partes. El juez puede rechazar un medio de prueba propuesto por la parte, pero no puede practicar un medio de prueba no propuesto por ellas. Veremos después con más detalle los poderes probatorios del juez en el proceso civil.

3..$^{\circ}$ Además la actividad verificadora ha de realizarse conforme al procedimiento previsto en la ley, y no de cualquier otra forma. El principio de legalidad que informa todo el proceso civil, expresado en el artículo $1^{\circ}$ de la LEC, tiene aquí una especial incidencia, por cuanto el legislador sujeta a reglas precisas el cómo realizar la verificación.

4..$^{\circ}$ En la verificación no todo vale, esto es, no pueden sacrificarse derechos que se consideran superiores a la misma verdad, como se manifiesta de modo muy claro en la ilicitud de la prueba, que determina que determinados conocimientos no sirven para determinar qué hechos se entienden probados, de modo que el legislador ordena al tribunal que en la sentencia desconozca hechos que, sin embargo, se conocen.

Todo lo anterior nos indica, sin más, que la búsqueda de la verdad no puede ser la función de la prueba civil. Si los hechos controvertidos pueden ser sólo los afirmados por las partes, si los medios de prueba a practicar han de ser únicamente los propuestos por las partes y si todo se reduce a que mediante éstos se trata de verificar aquéllos, no hace falta más para convencernos de que la verdad está fuera del alcance de la prueba procesal. Y adviértase que no nos hemos referido a las reglas legales de valoración de la prueba.

\section{B) Las clases de verdad}

Descartada la concepción anterior, la doctrina distinguió entre clases de verdad con referencia a las clases de procesos. Se pasó a sostener que si en el proceso penal la función de la prueba debía seguir siendo la búsqueda de la verdad, que se calificó de material, en el proceso civil bastaba con una verdad que se llamó formal. Si el juzgador estaba jurídicamente limitado en la búsqueda de los hechos, el resultado de la 
actividad probatoria se admitió que no podía ser la "verdad verdadera", sino simplemente una verdad jurídica, no basada en las leyes de la lógica sino fundada en las leyes jurídicas.

La distinción anterior era y es absurda pero fue sostenida por la doctrina (sobre todo la alemana) durante décadas y, sobre todo, permitió a los procesalistas penales diferenciar la prueba penal de la civil. El mito de la verdad formal fue destruido por Carnelutti, simplemente evidenciando que la verdad no puede ser más que una, de modo que, o la verdad formal coincide con la verdad material, y no es más que verdad, o discrepa de ella, y no es sino una no verdad ${ }^{67}$.

La claridad de la inexistencia lógica de clases de verdades, que sólo se explica desde la persistencia de un mito que está más allá de la razón, no está impidiendo que aún en la actualidad se haga referencia en ocasiones, y hasta en sentencias de los más altos tribunales, a la verdad material, o a que al tribunal no puede conformarse con la verdad formal y a otras expresiones de este género.

\section{C) Las funciones de la prueba}

A partir de la destrucción del mito, la doctrina se ha dividido en corrientes no muy bien perfiladas, en cuanto las diferencias entre unas y otras son de matiz, si bien cabe distinguir entre:

\section{a) Fijar hechos}

Una cosa es la fijación de los hechos controvertidos u ordenación del uso de determinados procedimientos que sirven para establecer los hechos conforme a lo dispuesto en la ley, aunque no se consiga la verdad. La ley regula una serie de mecanismos que el juzgador tiene que utilizar como sistemas únicos para llegar a la fijación de los hechos y esa fijación es la función de las normas probatorias. No se está haciendo exclusivamente referencia entre esas reglas a las legales de valoración de la prueba, ni a las que determinan cuándo un hecho es controvertido. Incluso la prueba de los hechos controvertidos, cuando se trata de la valoración libre, debe practicarse

67 Carnelutti, La prueba civil, 2. ${ }^{a}$ edición, traducción de Alcalá-Zamora, Buenos Aires, 1982, p. 37. 
conforme al sistema de la ley, y ese sistema no tiende al descubrimiento de la verdad sino a dejar establecidos formalmente los hechos de los que debe partirse en la sentencia.

Esas reglas son el resultado de pretender lograr la seguridad en la determinación de los hechos (utilizando las experiencias acumuladas para evitar errores) con economía en el esfuerzo (evitando la realización de actos superfluos). Naturalmente nada impide que con los medios jurídicos de fijación de los hechos se llegue realmente a descubrir la verdad, lo que por otra parte debe ser lo normal; lo que se dice en esta concepción es que la actividad probatoria se conforma con fijar los hechos necesariamente cumpliendo unas reglas jurídicas.

b) Convencer al juez

Y cosa distinta es la convicción psicológica del juzgador, con lo que prueba es el conjunto de operaciones por medio de las que se trata de obtener el convencimiento del juez respecto a unos datos procesales determinados. Abandonada la pretensión de obtener la verdad, es decir, la realidad objetiva de los hechos, aparece la función de lograr otra realidad, si bien subjetiva, la convicción del juez.

Naturalmente esta concepción se ve obligada a negar o a quitar valor a elementos que vienen impuestos por la ley. Dada la existencia en nuestro Derecho positivo de medios de prueba con valor legal (como veremos después), afirmar que la función de la prueba es lograr la convicción del juez supone desconocer esas reglas legales, y para ello se dice que las mismas son «un residuo histórico de viejas concepciones en trance de continua superación ${ }^{68}$.

Por otra parte la convicción acaba por referirse a la probabilidad. La certeza se produce cuando la inteligencia manifiesta la realidad de una afirmación, pero la certeza absoluta sólo puede producirse en el campo de la física o de la matemática, no en el del proceso, en el que sólo cabe una certeza moral, que se resuelve en la convicción, en cuanto medida psicológica de la certeza ${ }^{69}$.

68 Guasp, Derecho procesal civil, 2a edición, Madrid, 1962, p. 350.

69 Debe leerse Furno, Teoría de la prueba legal, traducción de González Collado, Madrid, 1954. 
c) La certeza

Hoy no puede mantenerse una concepción unilateral de la concepción de la prueba procesal por cuanto no cabe determinarla de modo absoluto, es decir, sin referencia a un determinado Derecho positivo. Es cierto que en los últimos años se tiende a hacer equivaler prueba con convicción judicial, pero ello debe matizarse como decimos a continuación.

Puede acabar así sosteniéndose que, consciente el legislador de la imposibilidad de obtener la verdad metafísica y la física, reconduce la prueba a la certeza respecto de las afirmaciones de hechos de las partes, si bien asume que esa certeza puede lograrse de varios modos:

1. $\left.{ }^{\circ}\right)$ Excluye de la prueba las afirmaciones de hecho de las partes sobre las que existe conformidad entre ellas, lo que se hace atendiendo a la naturaleza dispositiva del derecho material a aplicar.

2..$^{\circ}$ Establece unas veces en la ley y de modo reglado el valor que el juzgador debe conceder a un determinado medio de prueba, en el sentido de que configura la certeza independientemente del criterio subjetivo del propio juez, y ello hasta el extremo de que cabría referirse a una "certeza objetiva". Cuando la ley establece una norma de valoración lo que está diciendo es que, por ejemplo, la afirmación de hecho realizada por una parte que se ha verificado por un documento público ha de ser tenida como cierta por el juez.

3..$^{\circ}$ Otras veces dispone en la ley que el juzgador debe conceder a un medio de prueba el valor que estime oportuno conforme a las reglas de la sana crítica, con lo que la certeza se pone en relación con el convencimiento psicológico del mismo juez. En este caso cabría hablar de "certeza subjetiva", siempre que no se olvidara que no se trata de que el juez pueda decidir "en conciencia», pues la necesidad de motivar la sentencia ha de llevarle a exponer de modo razonado cómo ha llegado a formarse su convicción partiendo de los medios de prueba practicados.

El humilde abandono de la verdad y la consciente asunción de la certeza lleva a definir la prueba en nuestro Derecho positivo como la actividad procesal que tiende a alcanzar la certeza en el juzgador respecto de los datos aportados por las partes, certeza que en unos casos 
se derivará del convencimiento psicológico del mismo juez y en otros de las normas legales que fijarán los hechos.

\section{Los poderes del juez}

El 16 de octubre de 1939 (el año XVII después de la Marcha sobre Roma) Grandi, ministro de Justicia italiano, se dirigió a la Comisión de las Cámaras Legisladoras diciendo: «El juez es el órgano al que el Estado confía la función esencial de aplicar la ley por medio del procedimiento. En el fondo de la cuestión está el renovado concepto de la dignidad y de la autoridad del Estado fascista y de sus órganos, para los cuales no sería concebible que el juez asista, espectador impasible y, alguna vez, impotente, como si fuese un árbitro en un campo de deporte que se limita a contar los puntos y a controlar que sean observadas las reglas del juego, a una lucha que afecta, por el contrario, directamente a la celosa y a la más alta función y responsabilidad del Estado. Es necesario, por tanto, que el juez tenga una precisa dirección del proceso, una posición preeminente y reguladora ${ }^{70}$.

Después, con ocasión de la Relazione al Re que precede al Código procesal civil, el 28 de octubre 1940 insistió en la necesidad de reforzar los poderes del juez en la dirección del proceso civil y, consecuencia de ello, fue que el Código dedicara un Título (el V del Libro I) a «De los poderes del juez" pero, sobre todo que en materia de prueba se le atribuyeran poderes de oficio que ponen en duda su imparcialidad, como es el caso de: 1) Acordar en cualquier momento del proceso el interrogatorio de las partes (Art. $\left.117^{\circ}\right), 2$ ) Acordar el reconocimiento de personas y de cosas (Art. 118 $)$, 3) Diferir el juramento supletorio (arts. $240^{\circ}$ y $241^{\circ} \mathrm{CPC}$ y $2736^{\circ} \mathrm{CC}$ ), 4) Formular al testigo todas las preguntas que estime útiles para esclarecer los hechos (Art. 353 $)$, 5) Decretar careos (Art. 254 $4^{\circ}$, 6) Llamar como testigos a personas cuyo nombre se ha conocido por la declaración de otro testigo (Art. $257^{\circ}$ ), etc., y sin olvidar que en el proceso de trabajo el Art. $421^{\circ}$ permite al juez acordar cualquier medio de prueba y en cualquier momento.

En este mismo orden de cosas se comprende que la doctrina italiana posterior al fascismo, y para mantener la vigencia del Código que, por

70 Así se dice en la Relazione al Re, apartado 12. 
alguna razón, se llamó de Mussolini, se esforzara en distinguir principios dentro del proceso civil. Se trató de distinguir entre el principio dispositivo y el principio de aportación de parte y, dentro de este segundo, entre aportación de los hechos y aportación de las pruebas ${ }^{71}$.

Antes de la caída del fascismo se hacía en España eco Guasp de la tendencia.a aumentar las facultades del juez, citando lo que estaba ocurriendo en Alemania (se entiende la nazi) y en Italia (obviamente la fascista) y se lamentaba de que en la mayoría de las legislaciones (es decir, en las legislaciones con raigambre liberal) continuara la regla adversa a la iniciativa del juez en el proceso civil. A la adopción de una reforma radical en esta materia se oponía -seguía diciendo Guasp- el obstáculo del principio dispositivo que se concebía, no como una simple corruptela o vicio práctico, sino como una regla científica que informaba toda la marcha del procedimiento. Ese principio se consideraba por Guasp «rutina mental», precisando que era necesaria una crítica íntegra de esta tendencia individualista de innegable y marcada ascendencia liberal ${ }^{72}$.

$\mathrm{Al}$ principio de la verdad objetiva (llamada también verdad material para contraponerla a la verdad formal) como principio de la actuación procesal de los tribunales soviéticos se han referido los juristas rusos, los cuales han puesto de manifiesto que en la legislación comunista el juez debe «indagar» para el descubrimiento de esa verdad. Más aún, «la independencia del Tribunal Soviético respecto de los hechos señalados por las partes y su derecho de investigar también otros hechos, sustanciales para el asunto, asegura la posibilidad de hallar la verdad en el litigio y la dilucidación de las verdaderas relaciones mutuas entre las partes y por ello la defensa efectiva y real de las personas que participan en el litigio" ${ }^{73}$. En este contexto la posibilidad de que el juez acuerde cualesquiera medios de prueba no es más que una consecuencia de la negación del principio dispositivo.

71 El estudio clave a destacar es el de Carnacini, Tutela giurisdizionale e tecnica del processo, Op. cit.

72 Que él intentó llevar a cabo en su obra «Juez y hechos en el proceso civil (Una crítica del derecho de disposición de las partes sobre el material de hecho del proceso)", Bosch, Barcelona, 1943; se ha publicado recientemente en Guasp, Estudios jurídicos, Madrid, 1996, p. 279 y ss.; la referencia a la urutina mental" en p. 280.

73 En Derecho procesal civil soviético, dirigido por Gurvich, traducción de Lubán y revisión de Héctor Cuadra, México, 1971, p. 227. 
Se entiende así que cuando se hace un resumen de los principios del proceso civil socialista se diga que se trata de: «la sustitución del poder de las partes respecto al desenvolvimiento del proceso por la iniciativa del juzgador, armoniosamente combinada con los derechos procesales de las partes en sentido estricto (poder de disposición respecto de la iniciación del proceso, derecho a defenderse, derecho a interponer recursos, etc.); poder de iniciativa probatoria a favor del juzgador, búsqueda de la verdad material; facultad del juzgador de la apelación de hacer valer motivos de impugnación no deducidos por la parte apelante [...] así como también la amplia participación de la Prokuratura en el procedimiento civil ${ }^{74}$.

Todavía cabe referirse a la Ordenanza Procesal Civil austríaca obra de Klein, que no puede dejar de representar la ideología base del reaccionario Imperio austro-húngaro de finales del pasado siglo, y con todo ello se acaba de comprobar que la referencias a la verdad material o al aumento de los poderes del juez respecto de la prueba se asientan en un maremagnum de ideas políticas aparentemente contradictorias pero que acaban por ubicarse todas ellas en una concepción antiliberal o, si se prefiere, propiciadora de los poderes del Estado y, en último caso, totalitaria.

Después de que en buena medida todos hemos seguido por ese camino, en alguna publicación, que hoy debe calificarse de pecado de juventud, la mayor parte inconscientemente y deslumbrados por el mito, aunque no podemos negar que incurrimos en negligencia por no someter a la crítica intelectual propia e irrenunciable lo que se nos ofrecía, algunos hemos empezado a recapacitar sobre el modelo de juez que está implícito en algunas ideologías y sobre lo que ese modelo significa de supervivencia de concepciones autoritarias, y estamos procurando poner distancia ideológica e intelectual de por medio. Nos estamos preguntando, por ejemplo, cómo pudimos desconocer que la distinción entre juez espectador, juez dictador y juez director que hizo AlcaláZamora tenía su origen, incluso terminológicamente, en la Exposición de Motivos del Código fascista de 1940.

74 Stalev, «El procedimiento civil en los estados socialistas miembros del C.A.M.E. Antecedentes, creación, desarrollo, tendencia fundamentales y soluciones: 1900-1975", en LXXV Años de evolución jurídica en el mundo, volumen III, México, 1978, p. 186. 
El poner distancia de por medio con concepciones autoritarias no fue lo que algunos grupos parlamentarios hicieron con ocasión del debate sobre la Ley de Enjuiciamiento Civil de 2000. Algunos siguen refiriéndose a :

1) «En la regulación del proyecto subyace una intervención del juez como mero espectador de la contienda, alejado y con poca capacidad de verdadero impulso procesal y de averiguación de la verdad material ${ }^{75}$.

2) "Encima, el juez, al margen de todo, contempla impertérrito una especie de combate, que se supone igualitario y leal, y no puede intervenir ni puede tratar de descubrir la verdad, sino que debe aceptar, en el sagrado principio de aportación de parte, la apariencia de verdad que le aporten libremente los ciudadanos. Ese es un modelo que no podemos compartir. Es un problema de fondo y no un problema anecdótico o de coyuntura ${ }^{76}$.

La confrontación entre los modelos de juez, uno garantista liberal y otro autoritario cuando no totalitario, que se produjo con ocasión del debate parlamentario sobre la Ley de Enjuiciamiento Civil se ha saldado con un resultado poco definido. Adviértase que:

1. ) Por un lado el Art. $282^{\circ}$ dice que la iniciativa probatoria corresponde a las partes, de modo que las pruebas se practicarán a instancia de parte.

2. $)$ Por otro el Art. 429.1, II, dispone para el final de la audiencia previa en el juicio ordinario que "cuando el tribunal considere que las pruebas propuestas por las partes pudieran resultar insuficientes para el esclarecimiento de los hechos controvertidos lo pondrá de manifiesto a las partes indicando el hecho o hechos que, a su juicio, podrían verse afectados por la insuficiencia pro-

75 Diario de Sesiones del Congreso de los Diputados. Pleno y Diputación Permanente. Año 1999, 25 de febrero, VI Legislatura, núm. 217. Sr. Lasagabaster Olazábal (Grupo Mixto, de Eusko Alkartasuna, p. 11632.

76 Diario de Sesiones del Congreso de los Diputados. Pleno y Diputación Permanente. Año 1999, 25 de febrero, VI Legislatura, núm. 217. Sr. Belloch Julbe (Grupo Socialista), p. 11637. 
batoria. Al efectuar esta manifestación, el tribunal, ciñéndose a los elementos probatorios cuya existencia resulte de los autos, podrá señalar también la prueba o pruebas cuya práctica considere conveniente. En el caso a que se refiere el párrafo anterior, las partes podrán completar o modificar sus proposiciones de prueba a la vista de lo manifestado por el tribunal».

3. $)$ Por fin, en las diligencias finales los medios de prueba se acordarán a instancia de parte, si bien el Art. 435.2 dispone: «Excepcionalmente, el tribunal podrá acordar, de oficio o a instancia de parte, que se practiquen de nuevo pruebas sobre hechos relevantes, oportunamente alegados, si los actos de prueba anteriores no hubieran resultado conducentes a causa de circunstancias ya desaparecidas e independientes de la voluntad y diligencia de las partes, siempre que existan motivos fundados para creer que las nuevas actuaciones permitirán adquirir certeza sobre aquellos hechos. En este caso, en el auto en que se acuerde la práctica de las diligencias habrán de expresarse detalladamente aquellas circunstancias y motivos».

Como puede comprobarse en la nueva LEC y en materia de poderes del juez en la prueba se ha llegado a una solución de compromiso entre la tendencia liberal, propia del proyecto de ley, y la concepción autoritaria, introducida por las enmiendas admitidas. Esta solución de compromiso conduce a la indeterminación del modelo de proceso y serán los jueces los que le den contenido. No hace falta tener mucha experiencia para estar convencido de que el juez español no hará uso de la facultad que le confiere el Art. 429.1, II de la nueva LEC.

Las concepciones sobre los poderes del juez están evidenciando como se puede estar muy próximo a la esquizofrenia. Respecto del proceso penal hemos asistido en los últimos años a la limitación de las facultades del tribunal del juicio oral, con el argumento de la imparcialidad judicial, y a pesar de que en él entra en juego la aplicación del Derecho penal, mientras que en el proceso civil se está propiciando el aumento de los poderes del tribunal, a pesar de que se trata de la aplicación del Derecho privado. La contradicción es tan evidente que puede creerse que algunas personas, al sostener las dos posturas, tienen que tener doble personalidad, pues no se explica de otro modo, aunque también pudiera ser que los mitos no dejen ver la realidad y que la ideología impida el uso de la razón crítica. 


\section{La valoración de la prueba}

El mito con mayor arraigo en materia de prueba es el atinente a que lo moderno y racional es el sistema de valoración libre de la prueba, pues el sistema de prueba legal responde a épocas ya superadas del Derecho. Vamos a intentar destruir este mito convencidos que se ha basado en la pereza mental.

\section{A) Los sistemas de valoración}

Los sistemas teóricos que se conocen como de prueba legal y de prueba libre no se refieren a la apreciación de la prueba, sino sólo a la valoración de la misma, y antes de entrar en su exposición general, y en la adecuación de nuestro ordenamiento procesal civil a ellos, es preciso delimitar su ámbito de aplicación.

a) Negativamente hay que diferenciar entre principio de legalidad y prueba legal. Si la actividad procesal responde en general al principio de legalidad, como dispone el artículo $1^{\circ}$ de la LEC, una parte de esa actividad, la probatoria, también está sujeta al mismo principio. En este sentido el principio de legalidad determina cuáles son los medios de prueba, de modo que las partes no pueden pedir ni el juez acordar actividad probatoria que no esté prevista en la ley, y cómo tienen que proponerse y practicarse esos medios, con la consecuencia de que la actividad que no se acomode a lo dispuesto en la ley no puede calificarse de verdaderamente probatoria, ni puede servir para declarar probadas afirmaciones de hechos de las partes.

b) Positivamente hay que precisar que la valoración de la prueba se refiere a la eficacia probatoria de las fuentes-medios, pero que son reglas legales de valoración tanto aquellas normas que disponen directamente el valor que debe concederse a una fuente-medio, como las que imponen o excluyen alguna fuente-medio para la prueba de un hecho determinado.

Las reglas legales de valoración a las que suele prestarse atención son aquellas que determinan el valor de un medio determinado de prueba, pero no son las únicas, pues reglas legales son también las normas que dicen que un hecho determinado sólo puede probarse por un o unos 
medios concretos de prueba y que excluyen unas fuentes-medios para probar un hecho concreto (caso del Art. $51^{\circ}$ Código de Comercio, según el cual la prueba testifical no basta por sí sola para probar la existencia de un contrato mercantil de cuantía superior a 1500 pesetas).

Precisado el alcance de los llamados sistemas de valoración de la prueba, hay que acercarse a los mismos sin el maniqueísmo habitual que parte de imputar a uno, el de la prueba legal, todas las aberraciones imaginables y al otro, el de la prueba libre, todas las perfecciones de este mundo. En los últimos tiempos ha proliferado una literatura, que difícilmente puede calificarse de científica, pues se ha partido en ella de un prejuicio deformador de la realidad.

\section{B) La prueba legal}

Para comprender lo que es el sistema legal de valoración de la prueba hay que empezar por decir que el mismo en la actualidad no tiene nada que ver ni con la prueba ordálica ni con la prueba apriorística, sino que responde a lo que podemos considerar la certeza objetiva. A pesar de ello estimamos necesario hacer referencia a esos otros sistemas de valoración de la prueba, pues uno y otro se citan como variantes del sistema legal cuando realmente no hay tal.

\section{a) La prueba ordálica}

Todavía hoy es un lugar común decir que el origen de las reglas legales de valoración de la prueba se encuentra en la creencia de la intervención divina en todos los acontecimientos humanos, lo que tuvo especial importancia en el sistema jurídico germánico de las ordalías. Estas eran un juicio de Dios que el juez se limitaba a constatar, dando la razón a aquella de las partes a la que el mismo Dios se la había dado antes.

Las ordalías se basaban, por un lado, en la ignorancia y, por otro, en la superstición; en la ignorancia de las relaciones de causa y efecto en los fenómenos de la naturaleza, y en la superstición de que todo dependía de la voluntad de Dios. Sólo desde estas perspectivas pueden explicarse las ordalías del duelo, del fuego, de la suerte, de la cruz y tantas otras. En ellas se trataba básicamente de que Dios se manifestaba haciendo que venciera en el combate quien tenía razón, no el más fuerte ni el más diestro con las armas, que no sufriera que- 
maduras o, por lo menos, que no fueran graves el inocente que tenía que caminar sobre hierros ardientes o que tocarlos, que sostuviera los brazos más tiempo en alto el litigante que decía verdad, etc.

Independientemente de la crueldad que pudieran significar todos estos medios para establecer la verdad de los hechos, lo más destacable de los mismos es la irracionalidad en la que descansan, que es propia de las sociedades más arcaicas, sin perjuicio de que el elemento de la fe religiosa haya hecho que alguna de esas ordalías se mantuviera durante largo tiempo, tanto que todavía pueden encontrarse restos en la Edad media. Conviene destacar, con todo, que las Partidas prohibían expresamente la «lid de caualleros o de peones" (III, XIV) y que la confesión bajo tortura no tenía valor ni perjudicaba al confesante (III, XIII, 5).

b) La prueba apriorística

Desterrado el sistema de las ordalías, lo típico del proceso común fue el establecimiento de toda una serie de reglas que determinaban el valor probatorio de todos y cada uno de los medios de prueba, tasándose así el resultado al que podía llegar el juez atendidas las pruebas practicadas. El establecimiento de un sistema legal completo y cerrado en torno al valor de las pruebas tuvo muy variados fundamentos, pero pueden destacarse dos:

1. $\left.{ }^{\circ}\right)$ Filosóficamente se trataba de primar lo abstracto y general sobre lo concreto y especial, lo cual era propio de la filosofía escolástica o, por lo menos, de la degeneración de ésta. Esta concepción filosófica influyó en todos los saberes y si pudo limitar la experimentación, pudo también hacer preferir las abstracciones apriorísticas sobre el razonamiento individual del juez, como método que parecía más seguro para llegar a descubrir la verdad.

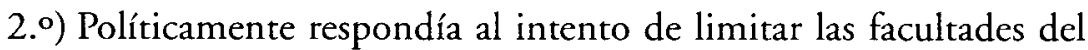
juez que es, aunque parezca paradójico, algo típico de los estados absolutistas en los que, concentrado el poder en unas manos y actuando los jueces por delegación del titular del poder absoluto, éste pretende controlar lo que hacen aquéllos. Ese control se manifestaba en muy variados órdenes y así se establecía una cadena de recursos que podía llegar hasta el mismo ti- 
tular del poder, se fijaban las reglas legales de valoración de la prueba y se disponía que el proceso fuera exclusivamente escrito, de modo que la sentencia no podía basarse en la inmediación, es decir, en lo visto y oído directamente por el juez, sino que tenía que atender a lo que constara en los autos por escrito, pues quod non est in actis non est in mundo.

De todo esto resultaba que la prueba apriorística no tenía nada que ver con la prueba ordálica sino que, en un determinado ambiente cultural, pretendía limitar los poderes del juez. Las reglas legales pudieron terminar siendo una garantía del ciudadano frente al juez, pero en su origen fueron producto de la desconfianza del titular del poder frente a sus propios jueces, a los cuales no se dejaba en libertad para establecer los hechos que debían considerarse probados.

c) Las máximas de la experiencia legales

La prueba legal a la que cabe dar hoy sentido no tiene relación ni con la prueba ordálica ni con la prueba apriorística, aunque en esta última estaba ya el germen de lo que es decisivo para el sistema de la verdadera prueba legal: las máximas de la experiencia. Las reglas que el soberano imponía a sus jueces, para determinar los hechos probados, no eran absurdas ni producto de la arbitrariedad; podían ser, desde la perspectiva actual, discriminatorias por razón de raza, religión, sexo o condición social, pero en general respondían a la concepción que se tenía de las relaciones sociales y a verdaderas máximas de la experiencia.

La prueba legal que hoy defiende parte de la doctrina no es un rescoldo de la anterior prueba apriorística, ni la subsistencia de unas pocas reglas de las muchas que antes existieron, sino que es algo completamente diferente que encuentra su justificación en la seguridad jurídica. El punto de partida consiste en comprender:

1.') La valoración de la prueba es una operación mental que se resuelve en un silogismo en el que: 1) La premisa menor es la fuente-medio de prueba (el testigo y su declaración, el documento y su presentación), 2) La premisa mayor es una máxima de la experiencia, y 3) La conclusión es la afirmación de la existencia o de la inexistencia del hecho que se pretendía probar. 
2. ${ }^{\circ}$ Las máximas de la experiencia, según la clásica definición de Stein, «son definiciones o juicios hipotéticos de contenido general, desligadas de los hechos concretos que se juzgan en el proceso, procedentes de la experiencia, pero independientes de los casos particulares de cuya observación se han deducido y que, por encima de esos casos, pretenden tener validez para otros nuevoss ${ }^{77}$.

El mismo Stein aplicaba este concepto a la valoración de la prueba, poniendo de manifiesto como juegan las máximas de la experiencia en la misma. Al considerar la declaración de un testigo no puede dejarse de tener en cuenta si es posible, según las leyes de la naturaleza, que una persona haya visto u oído lo que declara, cuando está claro que se encontraba a 150 metros del lugar del hecho; tiene que ponderarse igualmente si es verosímil, según nuestra experiencia, que un hombre recuerde con precisión lo que vivió siendo niño, etc., y lo que se está diciendo para el testigo es también aplicable, con las necesarias salvedades, a las restantes fuentes-medios de prueba.

3..$^{\circ}$ En el sistema de la prueba legal la máxima de la experiencia, que es la premisa mayor del silogismo, viene establecida por el legislador, el cual ordena al juez que proceda a aplicar esa máxima en el caso concreto, de modo que las reglas legales de valoración de la prueba no son más que máximas de la experiencia que el legislador objetiva, sin dejar que sea el juez el que determine la máxima de la experiencia que ha de aplicarse en el caso. Es decir, las reglas legales de valoración de la prueba son máximas de la experiencia legales.

En este esquema lógico el establecimiento por el legislador de reglas legales de valoración no es sino un método para conseguir la certeza, que es en lo que se resuelve toda actuación probatoria, método que no es, desde luego, contrario a la lógica, sino que responde a un criterio de normalidad jurídica derivado del id quod plerumque accidit. Desde la normalidad las reglas legales se justifican normalmente en la seguridad jurídica y, además, con un doble efecto; cuando el ordenamiento jurí-

77 Stein, El conocimiento privado del juez, traducción de De la Oliva, Madrid, 1990. 
dico establece que el documento público hace prueba, está dándole al juez un mandato para el caso de que en un proceso se presente esa prueba, pero también está, en el campo de las relaciones de derecho material, creando seguridad jurídica.

Si dos personas deciden otorgar en escritura pública un contrato pueden estar pensando en una doble seguridad jurídica; por un lado, la relativa a la certeza probatoria, pues la regla legal del artículo $1218^{\circ}$ del Código Civil español está preconfigurando la valoración futura dado que el juez no podrá desconocer el valor de la escritura pública, pero también están dando certeza a sus relaciones materiales por cuanto evitan dudas sobre el contenido de esas relaciones; esta segunda seguridad puede incluso evitar que llegue a ser necesario acudir al proceso, pues las partes conocen de antemano cuál será el resultado probatorio.

\section{C) La prueba libre}

Como en el caso anterior hay que advertir aquí que este sistema de valoración de la prueba no tiene nada que ver con lo que llamamos prueba discrecional o de la íntima convicción, sino que responde a la certeza subjetiva.

\section{a) La íntima convicción}

La ruptura con el sistema de la prueba apriorística se produce históricamente primero en el proceso penal y es obra de los ideólogos de la Revolución Francesa; esa ruptura estuvo íntimamente unida al establecimiento del jurado y acabó convirtiendo la valoración de la prueba en una declaración de voluntad y no de certeza o conocimiento. La legislación revolucionaria, pero sobre todo el Code d'instruction criminelle de 1808, partía de la soberanía del jurado, de que éste no podía estar vinculado por regla alguna para determinar los hechos que estimaba probados. La íntima convicción se resolvía así en dos postulados: 1) La valoración de la prueba no consiste en un ejercicio de la razón, sino en una declaración de voluntad, y 2) Esa declaración no tiene que ser motivada ${ }^{78}$.

78 El fundamento de este sistema se evidencia con toda claridad en el artículo $342^{\circ}$ del Code francés, que decía: «Antes de comenzar la deliberación, el jefe de los jurados dará lectura a la instrucción siguiente, que será, además, colocada en carac- 
Por este camino de la íntima convicción se acaba en la arbitrariedad y en la irresponsabilidad, y lo más grave es que se descubrió inmediatamente que la íntima convicción no tenía porqué ser exclusiva del jurado y del proceso penal, sino que podía también referirse a los jueces técnicos y al proceso civil. Voluntad discrecional, no motivación e irresponsabilidad son las notas que caracterizan el sistema de la íntima convicción, que se encuentra en la base, más o menos consciente, de las normas que refieren la valoración de la prueba a la conciencia del juez y de las sentencias que hablan de la facultad soberana del juzgador.

b) Las máximas de la experiencia judiciales

De la misma manera que la prueba legal no tiene verdadera relación con las pruebas ordálica y apriorística, la íntima convicción no está realmente relacionada con la prueba racional, que es la verdadera manifestación actual de la llamada prueba libre. Lo característico de este sistema de valoración de la prueba radica en que, del silogismo en que se resuelve esta operación mental, la premisa mayor, que es una máxima de la experiencia, es determinada por el juez. Esto conduce a una valoración razonada, motivada y responsable.

El acierto de la legislación española al referirse a la valoración de la prueba conforme a las reglas de la sana crítica radica, precisamente, en poner de manifiesto que prueba libre no es igual a prueba discrecional, sino a prueba en la que es el juez el que tiene que precisar las máximas de la experiencia utilizadas y desde las que ha llegado a su conclusión probatoria. Frente a otros ordenamientos en los que, como reacción

teres gruesos en el lugar más destacado de la sala: la ley no pide cuentas a los jurados de los medios por los cuales llegan a convencerse; no les impone regla alguna de la que deban hacer depender particularmente la plenitud y la suficiencia de una prueba; la ley sólo les ordena interrogarse a sí mismos en el silencio y en el recogimiento, y buscar, en la sinceridad de su conciencia, qué impresión han producido sobre su razón las pruebas aportadas contra el acusado y los medios de su defensa. La ley no les dice: tendréis por verdadero todo hecho declarado por tal número de testigos; ella no les dice tampoco: no considerareis suficientemente establecida toda prueba que no haya sido formada por tales documentos, de tales piezas, de tantos testigos o de tantos indicios; la ley no les hace más que una sola pregunta, que encierra toda la medida de sus deberes: ¿tenéis una íntima convicción?». 
contra la prueba legal, se pone el acento en la libertad del juzgador, el español pone el énfasis en la racionalidad que ha de estar en la base de la valoración.

Si la Ley de Enjuiciamiento Criminal, padeciendo la influencia francesa, dice en su artículo $741^{\circ}$ que «el tribunal, apreciando según su conciencia las pruebas practicadas en el juicio [...]», la Ley de Enjuiciamiento Civil de 1881, libre de esa influencia, decía en su Art. $659^{\circ}$, I, que «los jueces y tribunales apreciarán la fuerza probatoria de las declaraciones de los testigos conforme a las reglas de la sana crítica, teniendo en consideración la razón de ciencia que hubieren dado y las circunstancias que en ellos concurran». Por mucho que se insista en que uno y otro artículo están en el fondo diciendo lo mismo, no podrá negarse que, por lo menos, lo dicen de manera muy diferente. Hoy la LEC de 2000 sigue diciendo, aunque con mayor técnica que «los tribunales valorarán la fuerza probatoria de la declaraciones de los testigos conforme a las reglas de la sana crítica, tomando en consideración la razón de ciencia que hubieren dado, las circunstancias que en ellos concurran y, en su caso, las tachas formuladas y el resultado de la prueba que sobre éstas se hubiere practicado".

Para comprender lo que las reglas de la sana crítica suponen puede ser de interés recordar lo ocurrido inmediatamente después de la promulgación de la LEC de 1855, cuerpo legal en el que desaparecieron las reglas legales relativas a los testigos y aparecieron las reglas de la sana crítica. La doctrina se apercibió, sin más, del cambio efectuado pero advirtió que las reglas legales de las Partidas eran precisamente las reglas de la sana crítica, de modo que incluso después de su derogación debían seguir siendo aplicadas, aunque ahora en tanto que reglas fundadas en la crítica racional y en la buena lógica, como seguras guías moderadoras del arbitrio judicial. Por su parte la jurisprudencia sostuvo primero que las reglas de la sana crítica se correspondían con las anteriores reglas legales de valoración, después admitió que las reglas legales de las Partidas habían sido derogadas por la LEC y ha acabado por sostener que la sana crítica se corresponde con la lógica, con la experiencia empírica, con las máximas de la experiencia.

Hemos llegado a donde pretendíamos: las reglas de la sana crítica son máximas de la experiencia judiciales, en el sentido de que se trata de máximas que deben integrar la experiencia de la vida del juez y que éste debe aplicar a la hora de determinar el valor probatorio de cada 
una de las fuentes-medios de prueba. Esas máximas no pueden estar codificadas, pero sí han de hacerse constar en la motivación de la sentencia, pues sólo así podrá quedar excluida la discrecionalidad y podrá controlarse por los recursos la razonabilidad de la declaración de hechos probados.

\section{D) El sistema mixto de valoración de la prueba}

En el ordenamiento español no rige en exclusiva uno de los dos sistemas puros de valoración de la prueba, sino que se ha optado por un sistema mixto, en el que se han pretendido combinar armónicamente algunas reglas legales con la sana crítica.

a) Reglas legales

1. $)$ Sobre documentos públicos: arts. $319^{\circ}, 320^{\circ}, 321^{\circ}, 322^{\circ}$ y $323^{\circ}$ de la Ley de Enjuiciamiento Civil y arts. $1218^{\circ}$, I y II, $1219^{\circ}$, $1220^{\circ}$, I y II, $1221^{\circ}$, I, $1^{\circ}, 2^{\circ}$ y $3^{\circ}$, y II, del Código Civil.

2. $)$ Sobre documentos privados: Art. $326^{\circ}$ de la LEC y arts. $1225^{\circ}$, $1227^{\circ}, 1228^{\circ}, 1229^{\circ}$ y $230^{\circ}$ del CC.

3. $\left.{ }^{\circ}\right)$ Sobre interrogatorio de la parte: Art. 316.1 de la LEC (limitadamente).

4..$^{\circ}$ obre testigos: Art. $51^{\circ}$ Código de Comercio.

b) Sana crítica

Todos los demás medios de prueba se valoran de modo libre o, mejor dicho, conforme a las reglas de la sana crítica.

Ni siquiera después de la LEC de 2000 es cierto lo que el Tribunal Supremo lleva años diciendo respecto de que «en nuestro sistema procesal civil no se admite el principio de la prueba tasada, por lo que cualquier medio de prueba ha de ser libremente valorado por el tribunal de instancia” (STS de 2 de octubre de 1990, por ejemplo). Incluso después de la LEC de 2000 es evidente que con ello está desconociendo el espíritu y la letra de la ley.

Fijados cuáles son las fuentes-medios de prueba con valor legal conviene preguntarse ahora sobre su razonabilidad, es decir, sobre si está objetivamente justificado el mantenimiento de las reglas legales existentes en nuestro ordenamiento sobre la valoración de la prueba. Lo primero que hay que advertir es que las reglas legales existentes no pueden calificarse de ilógicas o absurdas, de modo que los argumentos 
a oponer contra ellas no pueden consistir en atribuirles nada contrario a la razón. Constituye máxima de la experiencia perfectamente razonable la de que debe ser creída la parte que reconoce hechos personales que la perjudican, la de que en las escrituras públicas los notarios hacen constar la fecha verdadera en que se otorga y reflejan con exactitud lo que dicen los contratantes, etc.

El mantenimiento o no de las reglas legales existentes no puede depender, por tanto, de que se niegue su razonabilidad. La verdadera cuestión es si, desde el punto de vista de la seguridad jurídica, es o no conveniente mantenerlas, y en este sentido es perfectamente defendible la subsistencia de las reglas legales atinentes a los documentos públicos, a los privados reconocidos y al interrogatorio de la parte.

\section{E) Valoración conjunta de la prueba y motivación de las sentencias}

Sea cual fuere el sistema de valoración de la prueba, lo inadmisible es la falta de motivación fáctica de las sentencias que viene propiciándose, sobre todo, a través de la denominada apreciación conjunta de la prueba. Y lo mismo cabe decir del desconocimiento consciente que la jurisprudencia ha venido haciendo de las reglas legales de valoración.

Empecemos por puntualizar que la apreciación conjunta no es rechazable en todos los casos; en algunos es necesaria:

1. $\left.{ }^{\circ}\right)$ Cuando varios medios de prueba se complementan entre sí o, incluso, cuando el resultado de unos incide en el resultado de otros. Ello puede suceder cuando existen varios testigos que declaran sobre un mismo hecho o cuando existen declaraciones testificales y documentos privados no reconocidos.

2..$^{\circ}$ Cuando existen pruebas cuyos resultados son contradictorios, pero teniendo siempre en cuenta que la contradicción ha de producirse entre pruebas que deban apreciarse por el mismo sistema:

1") Cabe así que ante medios de prueba que se aprecian libremente, por ejemplo, declaraciones testificales contradictorias (o entre declaraciones testificales y dictamen pericial contrapuestos), el juez tenga que apreciar en conjunto unas y otras para llegar al convencimiento que fuere. 
2") De la misma manera es posible la apreciación conjunta cuando la contradicción se produce entre medios de prueba de apreciación legal, pues entonces la aplicación de las dos reglas al mismo tiempo es imposible (como sería el caso del interrogatorio de varios demandados que, aun admitiendo hechos que les son perjudiciales, dijeran cosas contrapuestas).

La apreciación conjunta es inadmisible cuando la contradicción se produce entre medios de prueba que se aprecian por los dos sistemas, pues entonces lo que podría hacerse es desconocer las reglas legales, las cuales deben prevalecer sobre la prueba de libre apreciación. Si el resultado de una prueba legal quedara involucrado en una apreciación conjunta con pruebas libres, podría significar simplemente desconocer la prueba legal.

Esto es justamente lo que viene haciéndose en la práctica por los tribunales. La apreciación conjunta se utiliza tanto para desconocer el valor de las pruebas legales, como para no motivar fácticamente las sentencias. En el primer caso se llega por el Tribunal Supremo a decirlo expresamente. En el segundo caso la motivación fáctica de las sentencias no existe si no se ponen en relación las fuentes-medios de prueba con los hechos probados, y no se explica en la sentencia cómo desde aquéllos se llega a éstos, bien con base en el convencimiento del juzgador, bien con relación a las reglas legales. El Art. 120.3 de la Constitución viene siendo desconocido sistemáticamente en todos los casos en los que, mediante la fórmula «apreciadas en su conjunto las pruebas practicadas", se afirman como probados unos hechos sin más explicación o justificación, a pesar de que la STC 138/1991, de 20 de junio, ha admitido este sistema de la valoración conjunta.

\section{Conclusión}

\section{De vuelta a la realidad}

Llegados al final, es necesario reconocer que esta intervención no se ha limitado a examinar la nueva Ley de Enjuiciamiento Civil española desde la perspectiva del principio de oralidad, pero que el exceso ha sido necesario dado los sentidos que al principio se han pretendido dar. 
Después de haber renunciado a redactar la historia de la escritura y de la oralidad, he tenido que atender a una fase o etapa de esa historia, a aquélla en la que la oralidad dejó de ser un mero principio del procedimiento, es decir, un principio atinente a la forma de los actos procesales, para pretender convertirlo en algo que determinaba todo el sentido del proceso civil. Esa pretensión ha llevado al terreno mítico, propio de lo que es una ideología.

Después de casi todo un siglo de entrecruzarse de concepciones sobre el proceso civil, en el que lo más destacado ha sido el intento de desvirtuación de la realidad de que por medio de él se pretende la tutela judicial efectiva de derechos e intereses de naturaleza privada, para intentar convertirlo en un instrumento del Estado, por medio del juez, para atender a la mejor protección de los intereses públicos, con lo que evidenciaba que se trataba de someter lo privado a lo público, lo que era claramente revelador de una ideología autoritaria, para lo cual se ha pretendido utilizar a la oralidad, se está acabando de comprender, primero, que la oralidad sólo puede atender a los principios del procedimiento (forma) y, sobre todo, que el proceso civil tiene que seguir siendo el instrumento para la mejor protección de los derechos de naturaleza privada. Esto no puede entenderse que supone:

a) $\mathrm{Ni}$ el desconocimiento de la existencia de procesos civiles en los que ha de salvaguardarse un componente de interés público (estado y condición civil de las personas), procesos en los que no debería tratarse de aumentar los poderes del juez, sino de convertir en parte el Ministerio público, confiándose a éste la defensa de ese tipo de interés. El juez debería seguir siendo un tercero imparcial entre partes parciales, aunque una de las partes pretendiera la defensa un interés público.

b) Ni la negación de la existencia de supuestos en los que entra en juego un interés que pude calificarse de colectivo o difuso, casos en los que debería seguir manteniéndose un juez imparcial, y confiar la defensa de esos intereses a entidades o personas jurídicas constituidas con esa finalidad, de modo que se produjera una socialización de la legitimación, y un proceso social a base de aumentar los poderes del juez.

c) Ni la afirmación de que las partes son siempre efectivamente iguales en todos los procesos, pues ello va en contra de la experiencia. Ahora 
bien, este reconocimiento de la realidad no puede llevar a convertir al juez el defensor de una de las partes, aunque sí debería llevar a favorecer en la regulación del proceso todas las instituciones favorecedoras de la igualdad real (como la ejecución provisional sin necesidad de prestar caución), aparte de facilitar con medias efectivas, aunque no procesales, el acceso de todos los ciudadanos a la justicia civil.

El fenómeno de la publicización del proceso civil, propio del siglo $\mathrm{XX}$, ha pertenecido a la mítica jurídica. Ahora se trata de volver a la realidad. Esta puede ser matizadamente distinta en cada país, como es obvio, y precisará de medidas adecuadas a cada caso, pero en todos ellos se trata de mantener la existencia de un proceso civil que siga siendo una drama que se desarrolla entre dos partes parciales, en contradicción e iguales y un tercero imparcial. 